\title{
The Coupled Aerosol and Tracer Transport model to the Brazilian developments on the Regional Atmospheric Modeling System (CATT-BRAMS) - Part 1: Model description and evaluation
}

\author{
S. R. Freitas ${ }^{1}$, K. M. Longo ${ }^{1,}$, M. A. F. Silva Dias ${ }^{1,2}$, R. Chatfield ${ }^{3}$, P. Silva Dias ${ }^{2}$, P. Artaxo $^{4}$, M. O. Andreae ${ }^{5}$, \\ G. Grell $^{6}$, L. F. Rodrigues ${ }^{1}$, A. Fazenda ${ }^{1,7}$, and J. Panetta ${ }^{1}$ \\ ${ }^{1}$ Center for Weather Forecasts and Climate Studies (CPTEC), INPE, Cachoeira Paulista, Brazil \\ ${ }^{2}$ Department of Atmospheric Sciences, University of São Paulo, Brazil \\ ${ }^{3}$ NASA Ames Research Center, Moffett Field, USA \\ ${ }^{4}$ Institute of Physics, University of São Paulo, Brazil \\ ${ }^{5}$ Max Planck Institute for Chemistry, Mainz, Germany \\ ${ }^{6}$ Cooperative Institute for Research in Environmental Sciences (CIRES), University of Colorado/NOAA Research-Forecast \\ Systems Laboratory, Boulder, CO, USA \\ ${ }^{7}$ Department of Computing Science, University of Taubaté, São Paulo, Brazil \\ *now at: Center for Space and Atmospheric Sciences, INPE, São José dos Campos, Brazil
}

Received: 20 April 2007 - Published in Atmos. Chem. Phys. Discuss.: 20 June 2007

Revised: 14 April 2009 - Accepted: 19 April 2009 - Published: 28 April 2009

\begin{abstract}
We introduce the Coupled Aerosol and Tracer Transport model to the Brazilian developments on the Regional Atmospheric Modeling System (CATT-BRAMS). CATT-BRAMS is an on-line transport model fully consistent with the simulated atmospheric dynamics. Emission sources from biomass burning and urban-industrial-vehicular activities for trace gases and from biomass burning aerosol particles are obtained from several published datasets and remote sensing information. The tracer and aerosol mass concentration prognostics include the effects of sub-grid scale turbulence in the planetary boundary layer, convective transport by shallow and deep moist convection, wet and dry deposition, and plume rise associated with vegetation fires in addition to the grid scale transport. The radiation parameterization takes into account the interaction between the simulated biomass burning aerosol particles and short and long wave radiation. The atmospheric model BRAMS is based on the Regional Atmospheric Modeling System (RAMS), with several improvements associated with cumulus convection representation, soil moisture initialization and surface scheme tuned for the tropics, among others. In this paper the CATT-BRAMS
\end{abstract}

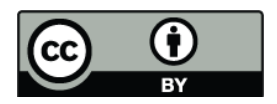

Correspondence to: S. R. Freitas (saulo.freitas@cptec.inpe.br) model is used to simulate carbon monoxide and particulate material $\left(\mathrm{PM}_{2.5}\right)$ surface fluxes and atmospheric transport during the 2002 LBA field campaigns, conducted during the transition from the dry to wet season in the southwest Amazon Basin. Model evaluation is addressed with comparisons between model results and near surface, radiosondes and airborne measurements performed during the field campaign, as well as remote sensing derived products. We show the matching of emissions strengths to observed carbon monoxide in the LBA campaign. A relatively good comparison to the MOPITT data, in spite of the fact that MOPITT a priori assumptions imply several difficulties, is also obtained.

\section{Introduction}

Biomass burning (vegetation fires) is a major anthropogenic source of greenhouse gases, aerosols and pollutants to the atmosphere during the dry season (July to October) over South America (Andreae, 1991; Artaxo et al., 2002; Andreae et al., 2004). Besides the contribution of greenhouse gases to the global warming, smoke aerosols have an impact on the radiative budget and cloud microphysics (Kaufman, 1995; Rosenfeld, 1999; Andreae et al., 2004; Koren et al., 2004) affecting the hydrologic cycle and boundary layer properties

Published by Copernicus Publications on behalf of the European Geosciences Union. 
(Longo et al., 2006a). In addition, smoke aerosols as well as ozone formation by biomass burning emission precursors are observed to frequently make the air quality of the neighbor areas even worst than for the South American Megacities, like São Paulo Metropolitan Region (Brazil Health 2006: an analysis of the health situation in Brazil, 2006, Artaxo et al., 2002). The emissions associated with several hundred of fires every day during the burning season and transported by the atmospheric motions, produces a huge plume of continental scale covering large areas around $4-5 \times 10^{6} \mathrm{~km}^{2}$ of South America (Prins et al., 1998; Freitas, 1999; Freitas et al., 2005b, 2006).

Numerical modeling is an important tool to study and forecast the impact of trace gases and aerosols on atmospheric evolution and air quality. Several atmospheric pollutant transport models on regional and global scales have been proposed in the literature. Chatfield et al. (1996) use the Global-Regional Atmospheric Chemistry Event Simulator (GRACES) to introduce a conceptual model of how fire emissions and chemistry produce the African/Oceanic plumes. The Georgia Tech/Goddard Global Ozone Chemistry Aerosol Radiation and Transport (GOCART) model is an example of a global transport model. Chin et al. (2000) employed GOCART to simulate the atmospheric global sulfur cycle. Chatfield et al. (2002) present a connection between tropical emissions and an observed subtropical plume of carbon monoxide at remote areas over the Pacific Ocean, using the GRACES and MM5 models. MOZART (Model of Ozone And Related Tracers) is an "off-line" global chemical transport model appropriate for simulating the threedimensional distribution of chemical species in the atmosphere (Brasseur et al., 1998; Horowitz et al., 2003). Grell et al. (2000) describe a multiscale complex chemistry model coupled to the Penn State/NCAR nonhydrostatic mesoscale model (MM5-CHEM). Other regional and fully coupled "online" transport models based on atmospheric models use the Regional Atmospheric Modeling System (Freitas et al., 2005b; Wang et al., 2006) and the Weather Research \& Forecasting Model (Grell et al., 2005; Fast et al., 2006), to name a few.

In this paper we describe and evaluate the Coupled Aerosol and Tracer Transport model to the Brazilian developments on the Regional Atmospheric Modeling System (CATT-BRAMS) 3-D atmospheric transport model. CATT is an "on-line" transport model fully coupled to the BRAMS atmospheric model and has been designed to study emission, deposition and transport of gases and aerosols associated with biomass burning in South America (SA). BRAMS is derived from the Regional Atmospheric Modeling System (Walko et al., 2000) and contains a set of new features to better represent the tropical and sub-tropical physical processes that drive the atmosphere over this region. Here, this modeling system is used to simulate the 2002 dry season in SA, when and where the LBA (Large Scale Biosphere-Atmosphere Experiment in Amazonia - http://www.lbaeco.org) field campaigns Smoke, Aerosols, Clouds, rainfall, and Climate (SMOCC) and Radiation, Cloud, and Climate Interactions in the Amazon (RaCCI) during the dry-to-wet transition season took place. The paper is organized as follows. It includes a description of the main BRAMS implementations developed by the authors to improve the atmospheric simulation over tropical and subtropical areas of South America. We decided to touch this subject because there is no paper that fully describes the new atmospheric components of the BRAMS modeling system,. The general features of the entire modeling system are described in Sect. 2 of the paper. Model configuration for the 2002 dry season simulation is introduced in Sect. 3. Section 4 explores model results and validation of these results based on observed data from the meteorological point of view as well as a general discussion about its performance. Model results for carbon monoxide and aerosol particulate material with size diameter less than $2.5 \mu \mathrm{m}$ are evaluated using near surface direct measurements, airborne and remote sensing retrieved data in Sect. 5. The final discussion and conclusions are reported in Sect. 6.

\section{Model description}

The model described in this paper is the CATT-BRAMS. BRAMS is based on the Regional Atmospheric Modeling System - RAMS (Walko et al., 2000) version 6 with several new functionalities and parameterizations. Throughout this text, while describing CATT-BRAMS, the original term RAMS will be used when the discussed parameterization was originally from the RAMS model, and the BRAMS term only for the aggregated Brazilian developments.

RAMS is a numerical model designed to simulate atmospheric circulations at many scales. RAMS solves the fully compressible non-hydrostatic equations described by Tripoli and Cotton (1982), and is equipped with a multiple grid nesting scheme which allows the model equations to be solved simultaneously on any number of two-way interacting computational meshes of increasing spatial resolution. It has a set of state-of-art physical parameterizations appropriate to simulate processes, such as surface-air exchanges, turbulence, convection, radiation and cloud microphysics. BRAMS features introduced by the authors include an ensemble version of a deep and shallow cumulus scheme based on the mass flux approach (Grell and Devenyi, 2002, hereafter GD). The original RAMS cumulus scheme was not based on mass flux approach, and for this reason was difficult to consistently include convective transport of tracers. Besides, the standard RAMS scheme, based on Kuo (1974) approach (Tremback, 1990), has strong coupling with the large scale moisture convergence, which is not in fact the main mechanism that generates convection on Amazon forest and cerrado areas during the dry season. In addition, Kuo scheme does not account for shallow non-precipitating convection. 
An operational off-line soil moisture estimation using RAMS based surface parameterization and remote sensing rainfall product was developed to daily provide the initial condition of this parameter (Gevaerd and Freitas, 2006). In addition, the trigger function of the convective parameterization uses the turbulence kinetic energy (TKE) of RAMS Planetary Boundary Layer (PBL) parameterization to modulate the maximum distance that air parcels can go up from their source level and, based on that, determine if a grid column will be able or not to sustain convection. GD scheme together with soil moisture initialization data and the triggerfunction based on TKE improved the simulation of Amazon basin moist convection spatial distribution as well as its temporal occurrence (Gevaerd et al., 2006a, b). We also improved BRAMS land use, soil type and normalized difference vegetative index (NDVI) data sets. The land use map for the Amazon basin was updated with data provided by the PROVEG project (Sestini et al., 2003) while the soil type in Brazil uses data from RADAMBRASIL project (Rossato et al., 2002). The NDVI is derived from the MODIS (Moderate Resolution Imaging Spectroradiometer) data based on 20012002 years, processed by the Terrestrial Biophysics and Remote Sensing Lab (tbrs.arizona.edu), converted to BRAMS data format and structure. The biophysical parameters maximum stomatal conductivity, leaf area index, albedo, roughness, biomass and soil heat capacity, soil porosity, hydraulic conductivity and moisture potential at saturation and root distribution associated with the vegetation and soil parameterizations of RAMS were adapted for tropical and sub-tropical biomes and soils, using observations or estimations obtained in recent field campaigns, mostly associated with the LBA program. Particularly, a correct description of the root distribution for the Amazonian forest was essential to simulate a realistic Bowen ratio during the burning season as showed in Freitas (1999). The original parameterization defined a too shallow root distribution for the Amazonian forest. As the evapotranspiration by the trees is strong and the season is characterized by a low rainfall amount, the correspondent soil layer dries out very quickly. As a consequence, the stomatal activity and the transpiration are reduced to a minimum. The original parameterization produces a warmer, drier and deeper PBL (up $2.5 \mathrm{~km}$ ) during the day, which is not consistent with the typical pattern Amazon PBL even during the dry season (Nobre et al., 1996). Its impacts on the tracer simulation are then an unrealistic strong dilution in the lower part of the troposphere and a weak transport to the layers above, by suppressing cumulus convection (Freitas, 1999).

CATT is a numerical system designed to simulate and study the transport and processes associated with biomass burning emissions. It is an Eulerian transport model fully coupled to BRAMS. The tracer transport simulation is made simultaneously, or "on-line", with the atmospheric state evolution, using exactly the same time-step as well as dynamical and physical parameterizations. The general mass continuity equation for tracers solved in the CATT-BRAMS model is (in a form of tendency equation)

$$
\begin{aligned}
& \frac{\partial \bar{s}}{\partial t}=\left(\frac{\partial \bar{s}}{\partial t}\right) \mathrm{adv}+\left(\frac{\partial \bar{s}}{\partial t}\right) \mathrm{PBL} \\
& \underbrace{}_{\mathrm{I}} \underbrace{\operatorname{diff}}_{\mathrm{II}} \\
& +\underbrace{\left(\frac{\partial \bar{s}}{\partial t}\right)_{\begin{array}{c}
\text { deep } \\
\text { conv }
\end{array}}}_{\text {III }}+\underbrace{\begin{array}{l}
\left(\frac{\partial \bar{s}}{\partial t}\right)_{\text {shallow }} \text { conv } \\
\text { sonv }
\end{array}}_{\text {IV }}+\underbrace{\begin{array}{c}
\left.\frac{\partial \bar{s}}{\partial t}\right)_{\text {chem }} \\
\mathrm{CO}
\end{array}}_{\mathrm{V}} \\
& +\underbrace{W_{\mathrm{PM}_{2.5}}}_{\mathrm{VI}}+\underbrace{R}_{\mathrm{VII}}+\underbrace{Q_{p r}}_{\mathrm{VIII}},
\end{aligned}
$$

where $\bar{s}$ is the grid box mean tracer mixing ratio, term (I) represents the $3-\mathrm{d}$ resolved transport term (advection by the mean wind), term (II) is the sub-grid scale diffusion in the PBL, terms (III) and (IV) are the sub-grid transport by deep and shallow convection, respectively. Term (V) is applied to $\mathrm{CO}$ which is treated as a passive tracer with lifetime of 30 days. Term (VI) is the wet removal applied to $\mathrm{PM}_{2.5}$, term (VII) refers to the dry deposition applied to gases and aerosols particles and, finally, VIII is the source term that includes the plume rise mechanism associated with the vegetations fires (Freitas et al., 2006, 2007). The advection at grid-scale uses the RAMS model formulation, a forwardupstream scheme of second order (Tremback et al., 1987). The parameterized sub-grid transport diffusion in the PBL uses also formulations contained in the RAMS model. Subgrid convective tracer transport by shallow and deep moist convection, which is fully consistent with the respective convective parameterizations, is also taken into account (Freitas et al., 2005b). Freitas et al. (2007) demonstrated that including convective transport of $\mathrm{CO}$ was essential do match model simulations with CO data from MOPITT instrument (Measurements of Pollution in the Troposphere, onboard the Earth Observing System Terra satellite), on the upper atmospheric levels over South America.

For smoke aerosol, a generic particle (without elemental composition specification) was assumed, with an average mass density of $1.35 \mathrm{~g} \mathrm{~cm}^{-3}$ (according Reid et al., 1998a) and spectral optical properties following the AERONET Amazonian climatology from Procopio et al. (2003). Wet removal of smoke aerosol particles is associated only with deep convection and coupled to the associated cumulus scheme in accordance with Berge (1993). Dry deposition processes are simulated using the resistance approach following Wesely (1989) and Seinfeld and Pandis (1998). It is fully coupled to the RAMS surface parameterization, including the patches approach (Walko et al., 2000). CATT is also coupled to the Brazilian Biomass Burning Emission Model (3BEM, Longo et al., 2007), which provides on a daily basis the total amount of trace gases and aerosol particles emitted by vegetation fires, as well as the quantities needed for estimation of the effective injection layer of the fraction released during the flaming phase. The data provided by the 3BEM model 


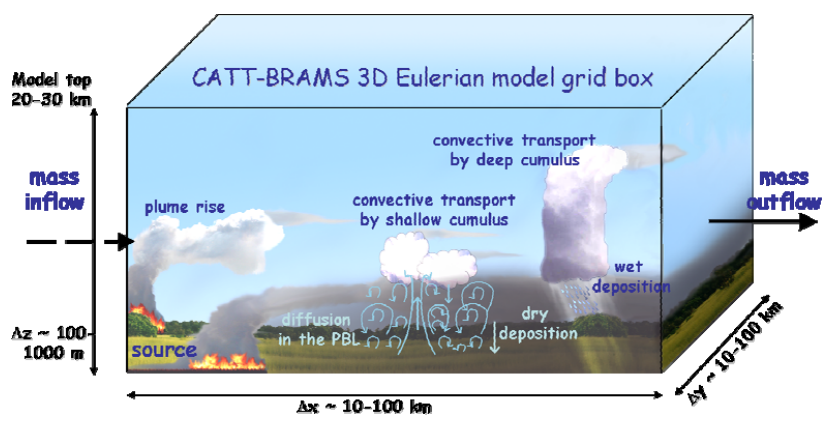

Fig. 1. Several sub-grid processes involved in gases/aerosols transport and simulated by CATT-BRAMS system.

is used by the CATT embedded plume rise model (Freitas et al., 2006, 2007) in order to determine term VIII of Eq. (1).

Figure 1 illustrates the main sub-grid scale processes involved in the trace gas/aerosol transport and simulated by the CATT-BRAMS system. Additionally, CATT-BRAMS includes a radiation scheme that takes into account the interaction between aerosol particles and short and long wave radiation. A consistent description of the smoke and its interaction with short- and long-wave radiation make the CATTBRAMS model reliable for atmospheric feedback studies of the smoke aerosols (Longo et al., 2006a, 2007).

BRAMS started as a software research project sponsored by the Brazilian funding agency FINEP (http://www. finep.gov.br) during 2002 and 2003. Project goals included software enhancements to achieve production quality code, maintaining research flexibility and improving the easiness to modify code characteristic. Since then, successive BRAMS versions are widely used in production mode at regional and statewide weather forecast centers and in research mode for the atmospheric and environmental sciences at universities all over Brazil. Follow-on projects such as GBRAMS (Souto et al., 2007) and SegHidro (Araujo et al., 2005) disseminated BRAMS as a platform for computer sciences research (e.g. Fazenda et al., 2006). Continuous collaboration and joint projects with RAMS development team maintained RAMS and BRAMS versions synchronized and kept consensus on software structure decisions over the years. BRAMS is supported and maintained by a software team at the Brazilian Center for Weather Forecasts and Climate Studies (CPTEC) that continuously transform research contributions (e.g. Freitas, 1999; Freitas et al., 2000, 2005b; Souza, 1999; Freitas et al., 2005a) generated at universities and research centers into production quality code to be incorporated in future code versions. BRAMS is an open source software freely available at http://www.cptec.inpe.br/brams.

\section{Model configuration and results for 2002 dry season simulation}

Simulations for the 2002 dry season were performed with CATT-BRAMS, and model results were compared with insitu observations and remote sensing retrieved data. The model was configurated with 2 grids: the coarse grid with $140 \mathrm{~km}$ horizontal resolution covering the South American and African continents, its main purpose was to simulate the intermittent smoke inflow from the African fires to South America and to coordinate with and compare to the longrange transport of smoke from fires in South America to the Atlantic Ocean; and a nested finer grid with horizontal resolution of $35 \mathrm{~km}$, covering only SA. The vertical resolution for both grids varies telescopically with higher resolution at the surface $(150 \mathrm{~m})$ with ratio of 1.07 up to a maximum vertical resolution of $850 \mathrm{~m}$, with the top of the model at $23 \mathrm{~km}$ (a total of 42 vertical levels). The soil model is composed of 7 layers with variable resolution, distributed within the first $4 \mathrm{~m}$ of soil depth. The total length of the time integration was 135 days, starting at on 15 July 2002 at 00:00 UTC. For the atmospheric initial and boundary conditions, the 6 hourly CPTEC T126 analysis fields of horizontal wind, geopotential height, air temperature and water vapor mixing ratio was used for the model initialization and to provide the necessary boundary condition using the traditional RAMS scheme, the 4DDA (four-dimensional data assimilation) technique. Initial soil moisture was taken from the Gevaerd and Freitas (2006) estimation technique, with data available at www.cptec.inpe.br/brams on a near real time basis. The soil temperature was initialized assuming a vertically homogenous field defined by the air temperature closest to the surface from the atmospheric initial data.

Figure $2 \mathrm{~A}$ shows the dominant vegetation characteristic of the regional nested grid. Figure $2 \mathrm{~B}$ introduces the initial water content $(\mathrm{mm})$ in the first $4 \mathrm{~m}$ of soil depth used to initialize the model soil moisture field. The horizontal distribution of the soil moisture shows strong correlation with the typical rainfall pattern during the dry season in SA. As expected, wet soils are found in the northwestern part of SA following the migration pathways of the convective systems; wet soils are also in the southeastern part of SA associated with precipitation of mid-latitude transient systems; and very dry soils in the central and northeastern parts of SA between the two wetter regions. The vertical PBL diffusion parameterization of RAMS used in this simulation was based on the Mellor and Yamada 2.5 closure (1982) formulation, which prognoses TKE. Two tracers emitted by biomass burning were included in this model simulation: carbon monoxide (CO) and aerosol particulate material with size diameter less than $2.5 \mu \mathrm{m}\left(\mathrm{PM}_{2.5}\right)$. The biomass burning emissions sources were distributed spatially and temporally and assimilated daily using the vegetation fire locations detected by remote sensing. $\mathrm{CO}$ and $\mathrm{PM}_{2.5}$ fields were initialized using horizontally homogeneous profiles associated with a 


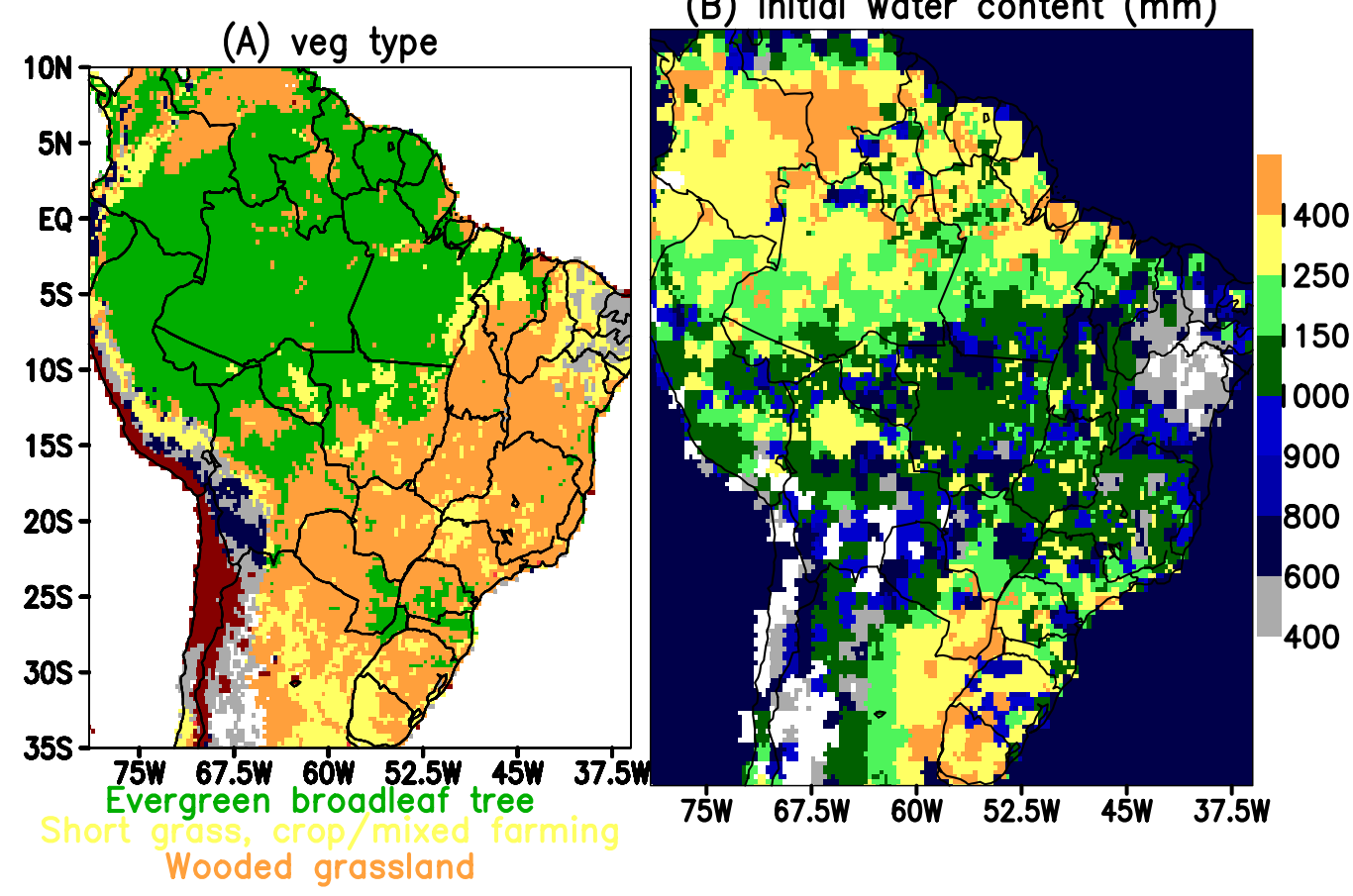

Fig. 2. (A) The dominant land-cover type used by model simulations at regional grid ( $35 \mathrm{~km}$ resolution). (B) The initial water content in the $4 \mathrm{~m}$ soil depth of model soil parameterization.

background situation and the model ran during a period of 15 days with sources for the spin-up. Lateral boundary condition was defined as constant inflow and radiative variable outflow. In this study, three sources of information on fire locations and properties were used: the Wildfire Automated Biomass Burning Algorithm product (Prins et al., 1998), the Brazilian National Institute for Space Research fire product (www.cptec.inpe.br/queimadas), and the MODIS fire product (Giglio et al., 2003); see Longo et al. (2007) for more details. Emissions from urban-industrial-vehicular activities and biogenic sources were not included in this paper, since in the areas were we focused model discussion and evaluation, biomass burning is by far the most important source. In that region, urban-industrial-vehicular activities are not well developed and biogenic process do not compete with the biomass burning processes used for land use changes during the dry season. Anthropogenic CO sources are mostly concentrated in the southeastern part of Brazil, Buenos Aires and Santiago areas, and in the Northwestern part of the South American continent, composing the main South American megacities and economical developed areas. In a separated simulation using urban anthropogenic as prescribed by the "REanalysis of the TROpospheric chemical composition" (RETRO, http://retro.enes.org) and biogenic as described by GEIA-POET (http://www.aero.jussieu. fr/projet/ACCENT/POET.php) inventories (not shown), the impact of these $\mathrm{CO}$ emissions on the central part of the continent and border of Amazon forest is found to be between 10 and $30 \mathrm{ppb}$ in a 3-monthy (August-September-October) mean basis. On the other hand, biomass burning contributes with CO that exceeds $100 \mathrm{ppb}$. Additionally, in the areas where SMOCC-RaCCI field campaign took place, this contribution is larger than $300 \mathrm{ppb}$ in the same 3 month average. These model results corroborate a report of methane and $\mathrm{CO}$ airborne measured in both fresh smoke plumes and regional haze dominated by smoke in Brazil, which did not find any statistically significant difference in the ration of methane to CO between fresh and aged smoke (Reid et al., 1998a, b). According to these authors, this is a good indicator that the regional hazes studied (which were within the model domain) were not significantly affected by urban anthropogenic sources.

Figure 3 shows an example of model output for $\mathrm{PM}_{2.5}$ vertically integrated $\left(\mathrm{mg} \mathrm{m}^{-2}\right)$ at 03:00 UTC on 21 October 2002, streamlines are at a height of $1.9 \mathrm{~km}$ above ground level (a.g.1.). The red box defines the nested grid domain with $35 \mathrm{~km}$ resolution where it is possible to visualize the finer scale structure. The typical model output, representing the tracer $\left(\mathrm{CO}\right.$ and $\left.\mathrm{PM}_{2.5}\right)$ simulated distribution and wind fields, expresses the connection between the atmospheric flows and the smoke transport. The role played by the anticyclonic circulation centered over the Atlantic Ocean promoting the 


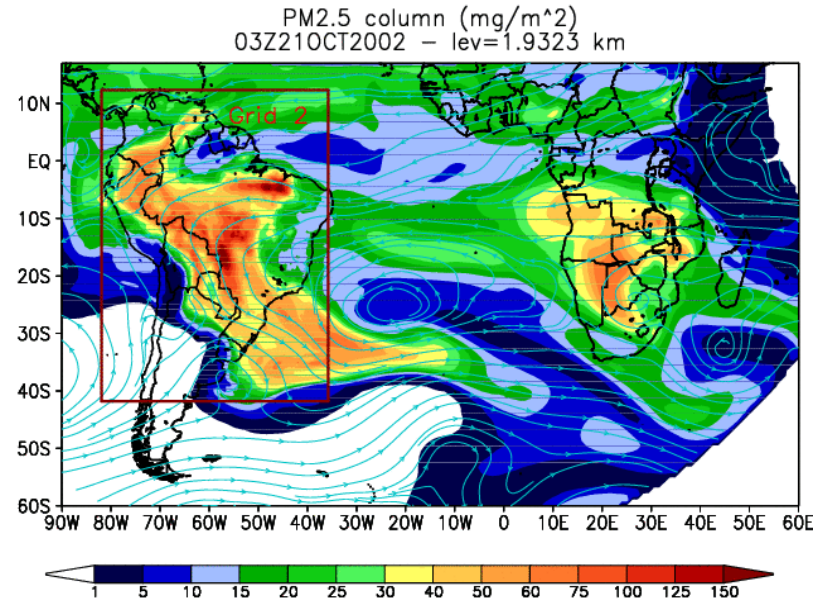

Fig. 3. Biomass burning particulate material with diameter less than $2.5 \mu \mathrm{m}$ vertically integrated $\left(\mathrm{mg} \mathrm{m}^{-2}\right)$. An example of model results for 03:00 UTC on 21 October 2002 at grids 1 and 2; the red box defines the domain of grid 2 with horizontal resolution of $35 \mathrm{~km}$.

smoke exchange between South American and African continents is seen as well as the long range transport of biomass burning emissions from SA http://www.atmos-chem-phys. net/9/2843/2009/acp-9-2843-2009-supplement.zip.

\section{Transport patterns and atmospheric model results}

\subsection{A conceptual model of how the typical South Amer- ican synoptic systems drive the transport of biomass burning emissions during the dry season}

Climatologically, from June to September, Central Brazil is dominated by a high-pressure area with little precipitation and light winds in the lower troposphere (Satyamurty et al., 1998) and with convection in the Amazon basin shifted to the northwestern part of South America. These conditions are associated with the westward displacement of the South Atlantic Subtropical High (SASH) and the northward motion of the Intertropical Convergence Zone (ITCZ) during the austral winter. However, on a day-to-day basis, several transient systems may change this mean picture, thereby altering the typical pattern of the smoke transport. The position of the SASH determines the inflow of clean maritime air into the biomass burning area, playing an important role in defining the shape of the regional smoke plume as it is the primary mechanism responsible for the dilution of the polluted air. Approaching cold frontal systems from the south are responsible for disturbances in atmospheric stability and in the wind field. These changes define the main corridors of smoke export to oceanic areas. Figure 4 introduces the fraction (or the percent persistence, PP) of the total simulation time (August, September and October 2002) when the simulated aerosol optical thickness (AOT) at $500 \mathrm{~nm}$ channel is above 0.5 . The parameter percent persistence clearly depicts the main areas heavily dominated by smoke. The accumulated number of fires per grid box observed by remote sensing in this time period and the three-month time average wind field at $1500 \mathrm{~m}$ a.g.l. are also shown. Not surprisingly, the main areas disturbed by fires at the western and central part of Brazil appear with PP around 90\%, which implies long term presence of high levels of air pollution, which may cause health problems in the local communities and impact on weather patterns. In the Northeast Region of Brazil, in spite of the huge number of fires, the PP is relatively low due the continuous venting of clean oceanic air carried by the trade winds, besides the low amount of the available fuel load in the vegetation. The trade winds carry out pollutant-laden air to the west, invading pristine areas of the Amazon basin and changing the chemical composition, the cloud microphysical properties, as well as the surface and atmosphere radiation budgets. The Andes Mountains on the east side of SA, together with the SASH, impose a long range transport of smoke from its source areas to the south and southeast parts of SA, thus disturbing larger areas downwind in the subtropics. The PP also shows the two major areas of inflow and outflow: to the north of the Equator a PP of $15 \%$ associated with the inflow of smoke from African fires; and a smoke outflow from SA fires to the southern Atlantic Ocean and to the African Continent (not shown).

\subsection{Model surface energy budgets and atmospheric re- sults and evaluation with observed data}

The main biomes disturbed by fires in SA, Amazon moist forest and wooded grassland (savanna, also named "cerrado"), present remarkable differences in the Bowen ratio (B) during the dry season. Because the root distribution of the Amazonia trees allows water removal from deep soil layers during the dry season, there is no restriction to keep the evapotranspiration as high as the typical values observed during the wet season (Hodnet et al., 1996). As a consequence, during the daytime the latent heat flux (LE) is approximately 3 times the sensible heat flux $(\mathrm{H}$ ), giving a $\mathrm{B} \sim 1 / 3$ (von Randow et al., 2004). Figure 5A shows the typical diurnal cycle of the fluxes LE and $\mathrm{H}$ observed during the dry season for a forest site (von Randow et al., 2004). Nobre et al. (1996) describe the typical time evolution of the PBL over the Amazon forest. The well developed mixed layer in the afternoon reaches about $1200 \mathrm{~m}$ a.g.l. However, in areas of deforestation, in which the original land cover is replaced by pasture, B is higher and, together with induced local circulations, determines a deeper mixed layer $(\sim 2200 \mathrm{~m}$ a.g.1.). For "cerrado" areas, Miranda et al. (1997) describe the typical surface fluxes during the dry season (Fig. 5B). The maximum values for the surface fluxes $\mathrm{H}$ and LE are 400 and $100 \mathrm{~W} \mathrm{~m}^{-2}$, respectively, with $\mathrm{B} \sim 4$. Usually, the mixed layer over cerrado in this time period reaches $2500 \mathrm{~m}$ a.g.l., as determined from the operational radiosonde of the 


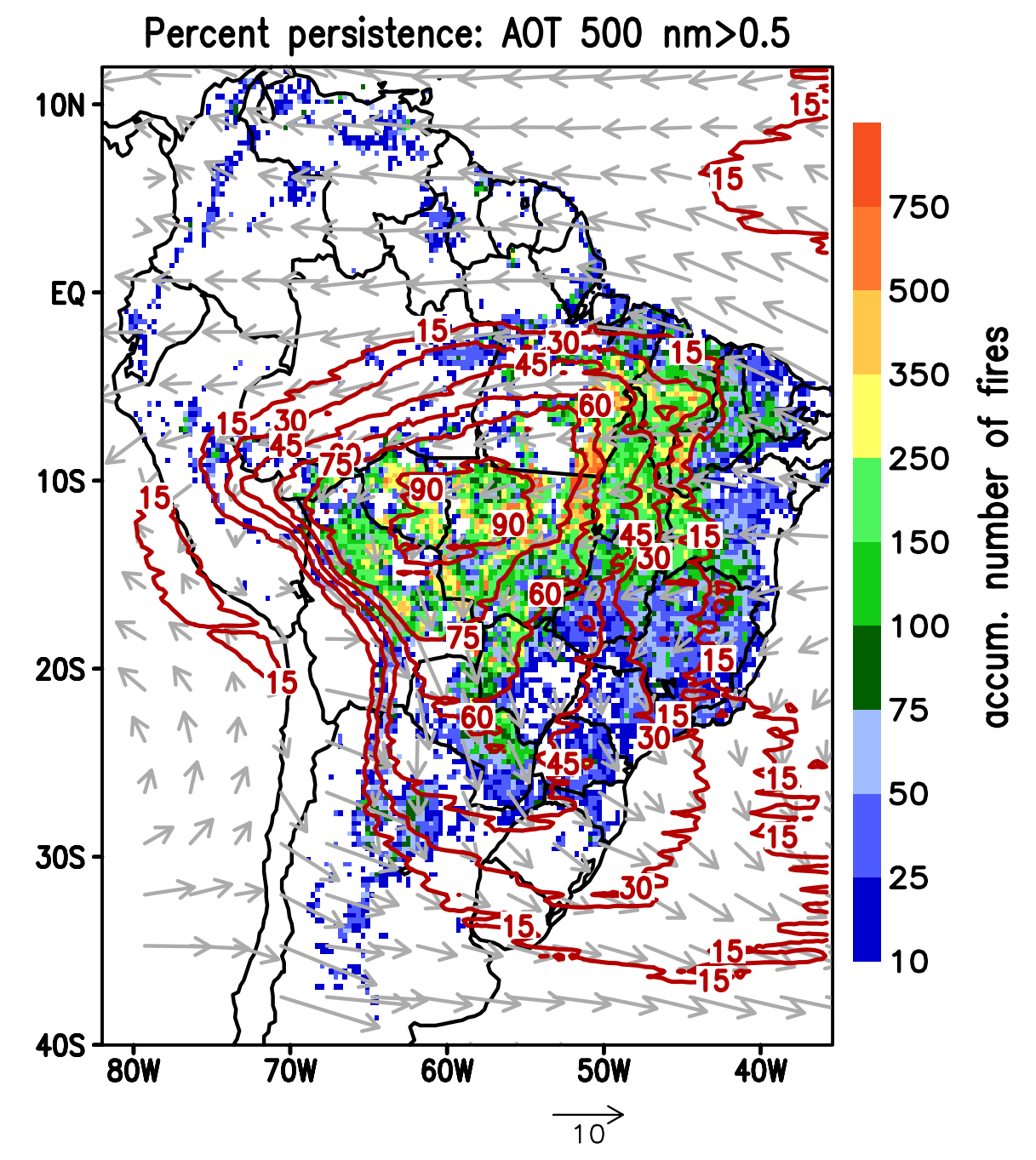

Fig. 4. In red contours, the 3 -month percent persistence of AOT at $500 \mathrm{~nm}$ greater than 0.5 . Indicated by color shading is the total number of fires per model grid box. The vectors correspond to the 3-month mean wind field at $1500 \mathrm{~m}$ a.g.l.

local airports. Three-month (August, September and October) time average of $\mathrm{H}$ and LE model simulation are shown in Fig. 5 for typical forest $(2 \mathrm{~S}, 65 \mathrm{~W})$ and "cerrado" (15 S, $48 \mathrm{~W})$ sites. The model results are in good agreement with the corresponding observations, which assures a realistic description of PBL properties for these biomes. The spatial distributions of $\mathrm{H}$ and LE as simulated by the model are shown in Fig. 6. These results are also the three-month time average at 15:00 UTC, which correspond to the daily peak value of $\mathrm{H}$ and LE. The model was able to consistently simulate the typical B for both forest and cerrado areas. At the southern part of Brazil, the high soil moisture associated mostly with large-scale rainfall from mid-latitude cold fronts was responsible for the low B, as expected. The impact of the described energy budget on the afternoon PBL depth is introduced in Fig. 7. The depth of mixed layer $\left(Z_{i}\right)$ at 18:00 UTC is shown and corresponds to the same time average mentioned before.
$\mathrm{Z}_{i}$ is lower over the ocean and in the areas affected by persistent rainfall systems. Over the Amazon basin the $Z_{i}$ ranges from 1000 to $1500 \mathrm{~m} . Z_{i}$ increases in the transitional areas from forest to deforestation and cerrado areas. On the central part of Brazil, $\mathrm{Z}_{i}$ peaks at approximately $2500 \mathrm{~m}$.

Model basic dynamic and thermodynamic quantities were evaluated using upper air observations with radiosondes launched during the SMOCC/RaCCI campaign. At two locations in Rondônia (Brazil), Ouro Preto do Oeste $\left(62.37^{\circ} \mathrm{W}, 10.75^{\circ} \mathrm{S}\right)$ and Reserva Biológica do Jaru $\left(61.91^{\circ} \mathrm{W}, 10.14^{\circ} \mathrm{S}\right)$, Six radiosondes were daily launched daily at approximately 00:00, 06:00, 12:00, 15:00, 18:00 and 21:00 UTC at two locations in Rondônia (Brazil), Ouro Preto do Oeste $\left(62.37^{\circ} \mathrm{W}, 10.75^{\circ} \mathrm{S}\right)$ and Reserva Biológica do Jaru $\left(61.91^{\circ} \mathrm{W}, 10.14^{\circ} \mathrm{S}\right)$, with a total of over 200 radiosondes for each location. Model air potential temperature, relative humidity, water vapor mixing ratio and zonal and meridional 


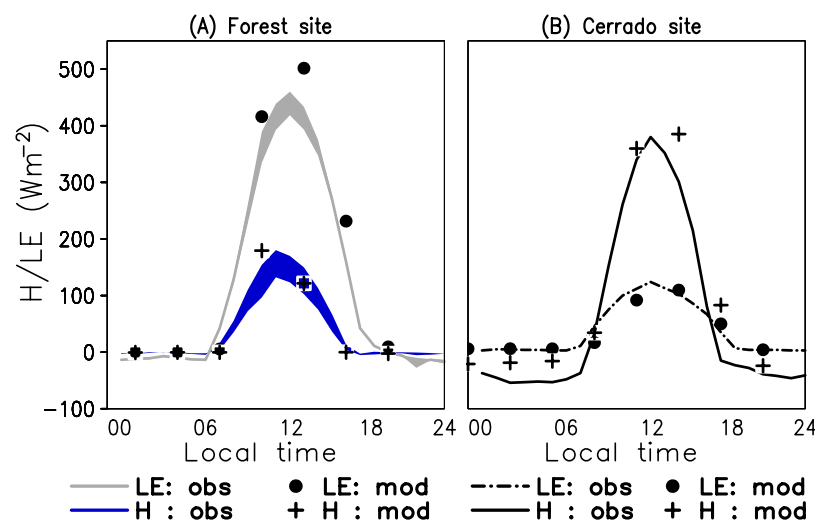

Fig. 5. The diurnal variability of sensible (H) and latent (LE) heat fluxes as observed at a typical Amazon basin forest site (A) and in central Brazilian cerrado areas (B) during the dry season. At the forest site (A), the shaded zone represents the two methodologies used by von Randow et al. (2004) for flux estimation. Model results are also shown using discrete dots (LE) and crosses $(\mathrm{H})$.

(A) latent heat flux $\left(\mathrm{W} / \mathrm{m}^{\wedge} 2\right)$

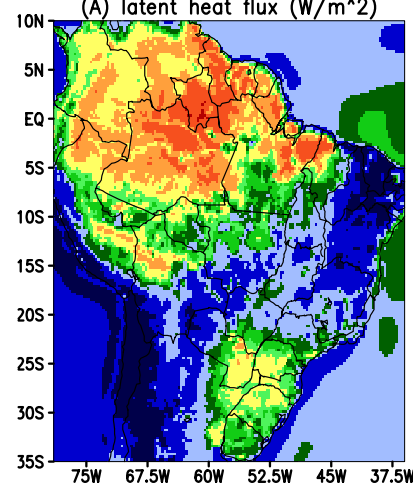

(B) sensible heat flux $\left(\mathrm{W} / \mathrm{m}^{\wedge} \mathrm{2}\right)$

Fig. 6. The spatial distributions of LE (A) and $H(\mathbf{B})$ as simulated by the model. The results correspond to the 3-month average at 15:00 UTC.

winds were compared with the respective observation data through the mean and standard deviation (STD), as shown in Fig. 8, Fig. 9 and Fig. 10. Only the Ouro Preto do Oeste results are shown, since those for Jaru are very similar.

Figure 11 depicts a statistical evaluation of the meteorological data available from the vertical profiling at the Ouro Preto do Oeste (OPO) site. In average the model yields a warmer near surface layer (Fig. 8) and a moister lower troposphere (Fig. 9) (below $600 \mathrm{hPa} \sim 4 \mathrm{~km}$ ). The removal of the bias leaves the RMS of about $2^{\circ} \mathrm{C}$ for the near surface temperature and between 0.5 and $1{ }^{\circ} \mathrm{C}$ for the rest of the atmosphere and $1.5 \mathrm{~g} \mathrm{~kg}^{-1}$ for the water vapor mixing ratio at low levels. Considering the model grid size of $35 \mathrm{~km}$ and the fact that OPO lies in a small valley with topography features not resolved by the model, such differences in temperature might be expected, especially near the surface level, even after re-

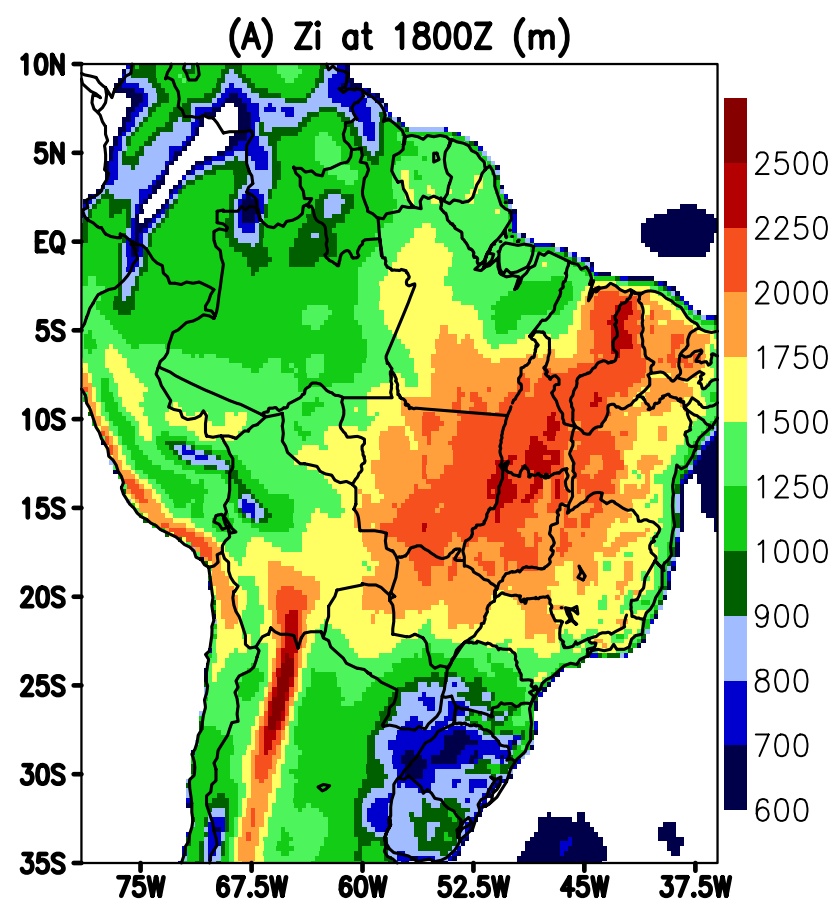

Fig. 7. The mixed layer depth obtained from the model TKE vertical profile. The result corresponds to the 3-month average at 18:00 UTC.

moving the bias, which would only account for the difference in altitude. The low level wind speed differences (Fig. 10) are relatively small but may also be explained by the effect of local circulations, at least in the first $2-3 \mathrm{~km}$, approximately. At upper levels, the unbiased RMS is relatively small compared to the standard deviation, suggesting good agreement between model and observations. The moister lower troposphere is associated with a lower STD for the model results, with an unbiased RMS larger than the model STD. The relatively low values are (less than $1.5 \mathrm{~g} \mathrm{~kg}^{-1}$ ) could be due: (1) the model does not include the absorption of water vapor by hygroscopic aerosol (Roberts et al, 2002); and (2) radiosonde observations are highly variable in the lower troposphere in terms of moisture, due to possible upward paths in cloudy and non-cloudy areas that are not reproduced by the model, which does not resolve individual clouds. The first argument would account for a moister model and the latter for the relatively high RMS.

Figure 8 also indicates a difference in stability between model and observations: the model is less stable in lower levels and more stable in upper levels than the observations. This indicates that some effect on the vertical dispersion of tracers may be expected. A warmer and moister surface would indicate that surface parcels are more easily lifted in the model; however a warmer and more stable middle to upper troposphere in the model would reduce cloud top and thus the depth to where clouds transport surface emissions. This will be discussed further in Sect. 5.1. 


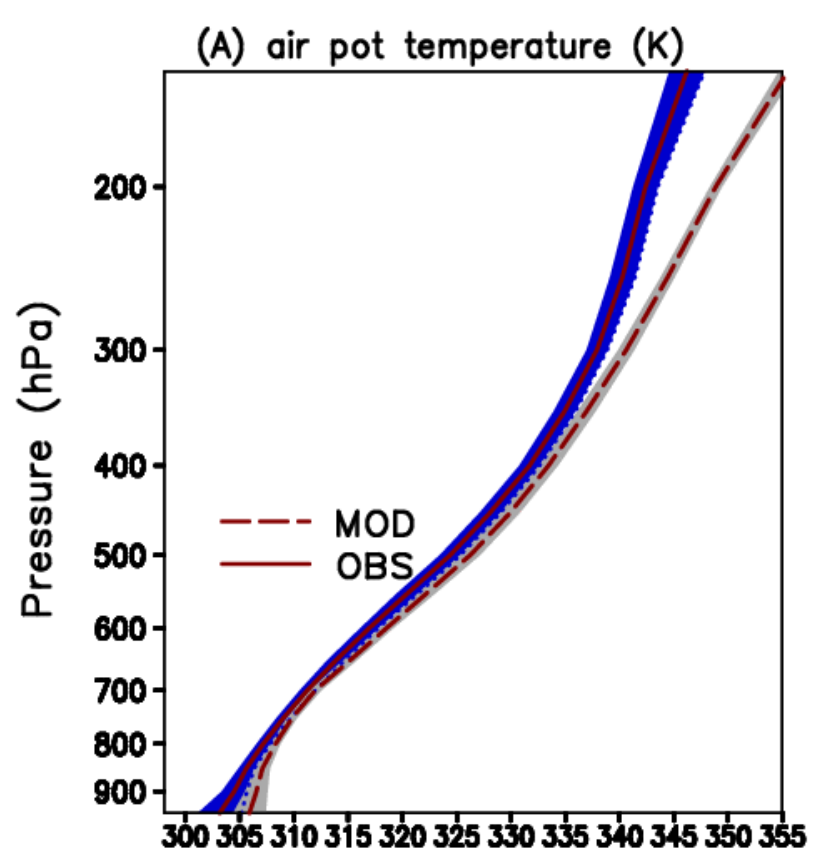

Fig. 8. Model and observed air potential temperature for Ouro Preto do Oeste, Rondonia, Brazil. The mean and standard deviation (shaded zones) for model (dashed line, grey) and observed (solid line, blue) are shown. The calculations were done using observations from 200 radiosondes launched during the SMOCC/RaCCI field campaign.

The model evaluation concerning the simulated total rainfall, from convective and large-scale systems, is based on the estimates provided by the Global Precipitation Climatology Project "One-Degree Daily Precipitation Data Set" product (GPCP, Huffman et al., 2001). Figure 12 shows the 3month (August, September and October) mean rainfall rate $\left(\mathrm{mm} \mathrm{day}^{-1}\right)$ as estimated by the GPCP product and as simulated by the CATT-BRAMS model. The model was able to consistently simulate the main patterns of rainfall, but with some disagreement in terms of mean rate. The model simulation of the ITCZ over the ocean appears with a lower rainfall rate, while over land it is higher compared to the GPCP retrievals. In the Southern region of Brazil and over the Atlantic Ocean, the model also simulates weaker rainfall rates. However, rainfall retrievals from satellite also present limitations. For example, underestimation of precipitation rates associated with clouds with low top height in the Amazon basin, and overestimation associated with rain falling in dry environments with consequent re-evaporation, like in Southern Brazil and Northern Argentina.

Note also that if we have confidence in the observations, the GD scheme may be statistically trained with observations to weight the ensembles that are used to determine the location and strength of the convection. This is especially
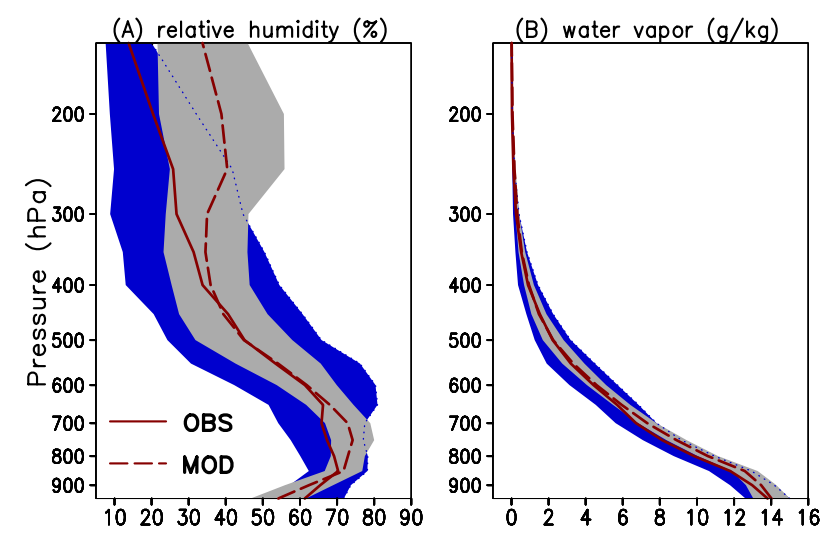

Fig. 9. The same as Fig. 8 but for relative humidity (A, \%) and water vapor mixing ratio $\left(\mathrm{B}, \mathrm{g} \mathrm{kg}^{-1}\right)$.
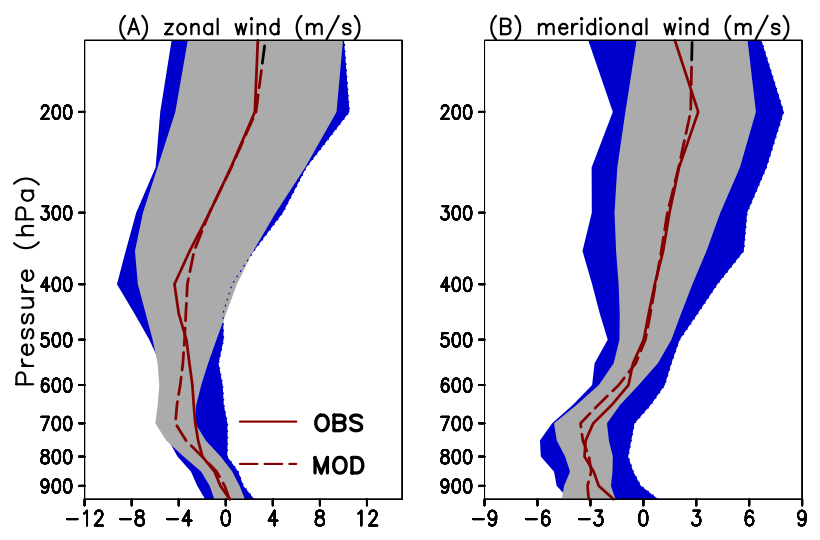

Fig. 10. The same as Fig. 8 but for zonal wind $\left(\mathrm{A}, \mathrm{ms}^{-1}\right)$ and meridional wind $\left(\mathrm{B}, \mathrm{m} \mathrm{s}^{-1}\right)$.

the case if a systematic behavior of any of the closures can be identified. However, in this work, not statistical training methods were used yet.

\section{Model $\mathrm{PM}_{2.5}$ and $\mathrm{CO}$ results and comparison with ob- served data}

\subsection{Model evaluation with SMOCC/RaCCI 2002 sur- face and airborne measurements}

In this section, we present model results for tracers on the $35 \mathrm{~km}$ resolution regional grid, as stated above. $\mathrm{CO}$ and $\mathrm{PM}_{2.5}$ near-surface measurements were made at the Ouro Preto do Oeste pasture site, during the SMOCC/RaCCI field campaign from 10 September to early November 2002 (Fuzzi et al., 2007). The $\mathrm{PM}_{2.5}$ particle mass concentration was measured with a TEOM (Tapered Element Oscillation Mass Balance) instrument near surface level with a 30min temporal resolution from 10 September to 4 November 2002. Figure 13 shows two time series with a comparison of surface $\mathrm{CO}$ and $\mathrm{PM}_{2.5}$ from the model and observation. 


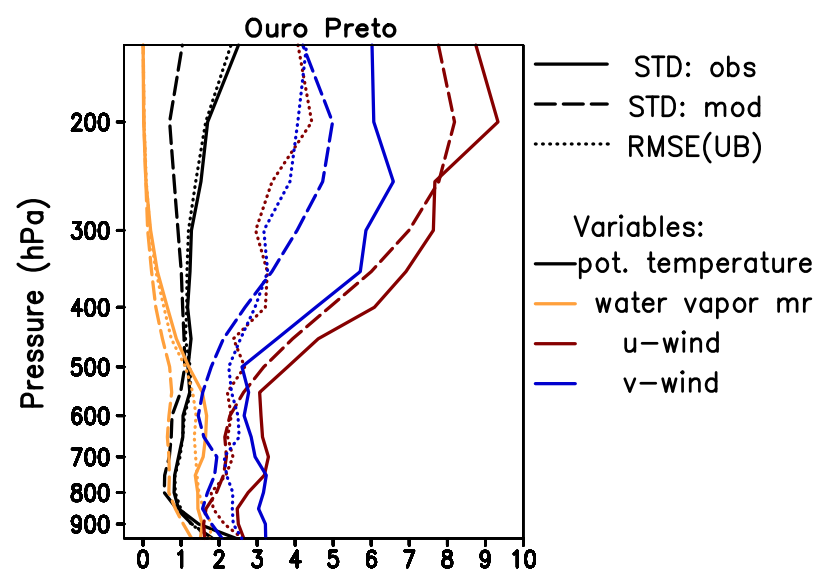

Fig. 11. Statistical evaluation of meteorological data for Ouro Preto do Oeste: potential temperature, water vapor mixing ratio, zonal and meridional wind. STD is the standard deviation and RMSE (UB) is the root mean square error after removing the bias (unbiased).

An intercomparison of the $\mathrm{PM}_{2.5}$ and $\mathrm{CO}$ model results at 12:00 UTC with the daily average of the measurements values centered at 12:00 UTC reveals good agreement in terms of the general pattern of the temporal evolution and values. The linear regression of the $\mathrm{PM}_{2.5}$ and $\mathrm{CO}$ observed values versus modeled values are also shown and presents high correlation $\left(R^{2} \approx 0.7\right)$. During the SMOCC/RaCCI field campaign, three very well characterized regimes of rainfall were observed. The period from 10 September to 8 October still shows the dry season characteristics with low precipitation rates and a high number of fires, not only in Rondônia state, but all over the Amazon basin and Central Brazil. This pattern is clearly reflected in the surface-level aerosol particle and CO measurements performed in Rondônia. During this period, high values of $\mathrm{CO}$ and $\mathrm{PM}_{2.5}$ were observed. The maximum values were as high as $4000 \mathrm{ppb}$ and $210 \mu \mathrm{g} \mathrm{m}^{-3}$, respectively, with the time series characterized by strong variability. Although the diurnal evolution of the boundary layer contributes to this high variability, it mainly indicates the proximity of fires to the measurement site. The peak values are typically the plumes that still have not been significantly dispersed. This may indicate that the observation was not representative of the regional scale; nevertheless the model values are within the STD of the mean observation range. Following this period, from 8 to 30 October there was an increase in precipitation and a consequent reduction of the occurrence vegetation fires. In Rondônia state, fires were rare but there were a few hot spots still observed in the region. By the end of October, the onset of the wet season drastically reduced the number of fire counts everywhere in South America. This pattern is clearly reflected in the surface-level CO and $\mathrm{PM}_{2.5}$ measurements performed in Rondônia and also in the model results. For both periods, the model agreements are fairly good.
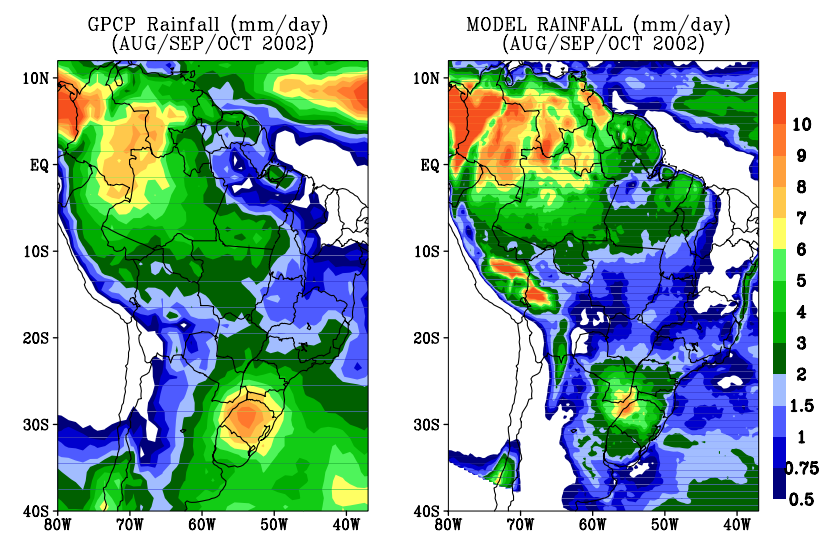

Fig. 12. (A) 3-month mean of rainfall rate as estimated by the GPCP product. (B) The same quantity as simulated by CATT-BRAMS model.

Comparison of simulated CO profiles in the PBL and lower troposphere with observed data were performed using SMOCC/RaCCI campaign airborne measurements (Andreae et al., 2004). The airborne component of SMOCC/RaCCI took place in the Amazon Basin during September and October of 2002. Carbon monoxide (CO) measurements during SMOCC/RaCCI were obtained onboard the INPE Bandeirante aircraft using an Aero-Laser (AL5002) instrument operating at $1 \mathrm{~Hz}$. The typical maximum altitude reached by the SMOCC/RaCCI aircraft was $5 \mathrm{~km}$. The measurement accuracy is better than $\pm 5 \%$; details can be found in Guyon et al. (2005). Figure 14 shows comparisons for sixteen flights. The mean and STD of the observed CO profiles are shown; note that STD represents the actual variability of the concentrations, not the measurement error.

The flights considered in this study took place over the state of Rondônia and North of Mato Grosso, one of the areas with the highest occurrence of vegetation fires in the Amazon basin. With fire spots widespread in the experimental area, the smoke spatial and vertical distribution was strongly inhomogeneous, as shown by the STD of the mean observations taken for the same vertical layers of the model. Very often the climbing and descending profiles show large differences, revealing the inhomogeneity of the aerosol concentration either due to the presence of isolated smoke plumes or very thin smoke layers detrained from convective systems and fire plume rise. As expected, the model resolution of $35 \mathrm{~km}$ did not allow the point-by-point reproduction of the effect of subgrid phenomena in the profiling. Nevertheless, it very well succeeded in representing the mean pattern of each airborne profile, with the model results almost always falling within the STD of the observations. The overall model performance can be evaluated in Fig. 15, where the mean CO observed profile and its STD are presented together with the mean CO model. The model result is very consistent with the observed mean, being always inside of the STD range. Figure 15 also 

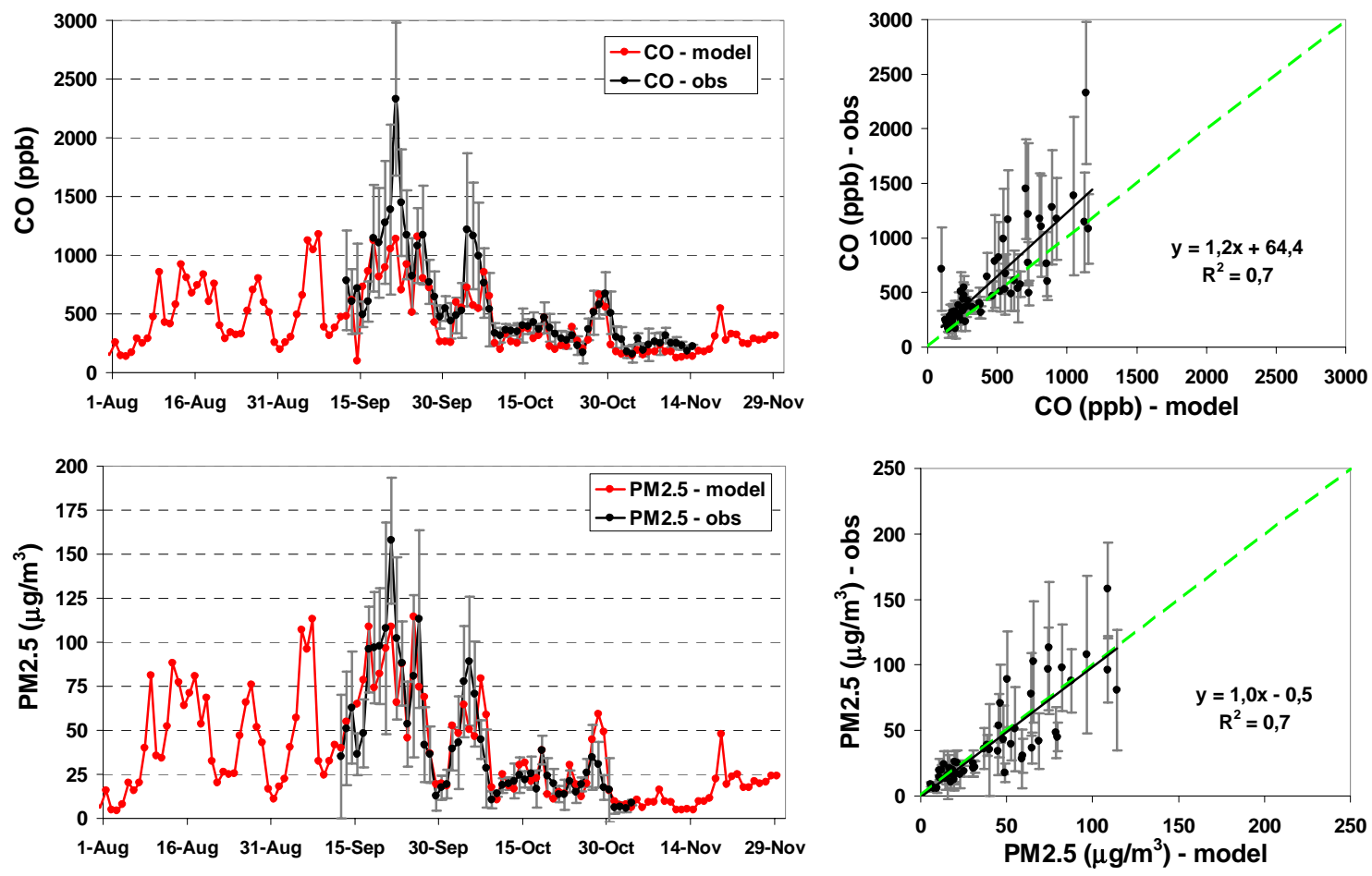

Fig. 13. Time series with comparison between near surface $\mathrm{CO}$ (ppb, top) and $\mathrm{PM}_{2.5}\left(\mu \mathrm{g} \mathrm{m}^{-3}\right.$, bottom) observed (black) and model results (red). The measurements were daily averaged and centered at 12:00 UTC. The error bars are the standard deviations of the mean values. The model results are presented as instantaneous values at 12:00 UTC.

indicates that the model is able to accurately capture the vertical distribution of the observed concentrations.

It is important to emphasize the difficulty for an "on-line" and coupled model to simulate observed profiles such as those associated with biomass burning, in view of the nonlinearities of the processes and the uncertainties in estimating the emission sources. Among the relevant uncertainties are: the realistic representation of the radiative transfer in the presence of aerosols, the adequate representation of water and heat surface fluxes that are strongly controlled by the soil moisture content and the PBL evolution, as well as an appropriate spatial and temporal distribution of the emission source strength, including the plume rise mechanism. As seen in Sect. 4, there are differences between model and observations concerning the stability in lower and upper layers. However, the results for the CO profile do not show a consistent bias that could be explained by the different impact of stability in the cloud transport of tracers. Also important is the appropriate definition of the regional boundary inflow and outflow through advective transport. In particular, the impact of dynamic feedback between aerosol and radiative field on $\mathrm{CO}$ simulation is discussed at the companion paper (Longo et al., 2007).

\subsection{Model comparisons with MOPITT data}

Model performance on larger scales, including upper troposphere levels, is evaluated in this section, using data retrieved by the MOPITT instrument. MOPITT retrievals of tropospheric CO mixing ratio (ppb) are reported for 7 pressure levels, from the surface to $150 \mathrm{hPa}$ (Deeter et al., 2003). The model results, after applying the averaging kernel and a priori profile, and using retrievals with $<50 \%$ a priori contribution, and MOPITT data were monthly averaged. This was done because MOPITT data have large horizontal areas without valid data due to swath width and cloud cover Fig. 16 shows the comparison for the months August, September and October on five vertical levels $(850,700,500,350$ and $250 \mathrm{hPa})$ at the large scale grid. The quantity depicted in the abovementioned figure is the relative model error (ME) defined as

$\mathrm{ME}=100 \times \frac{\mathrm{CO}_{\text {mopitt }}-\mathrm{CO}_{\text {model }}}{\mathrm{CO}_{\text {mopitt }}}$,

According to the above definition, positive values mean that model results are underestimated in reference to the MOPITT retrieved data and vice-versa. August is one of the driest months with few cases of convective systems over SA. Therefore ME is small and within a range of $10 \%$ above $500 \mathrm{hPa}$ (Fig. 16A, B and C). Below $500 \mathrm{hPa}$ (Fig. 16D and E) and on the central and north part of SA, ME is within a 

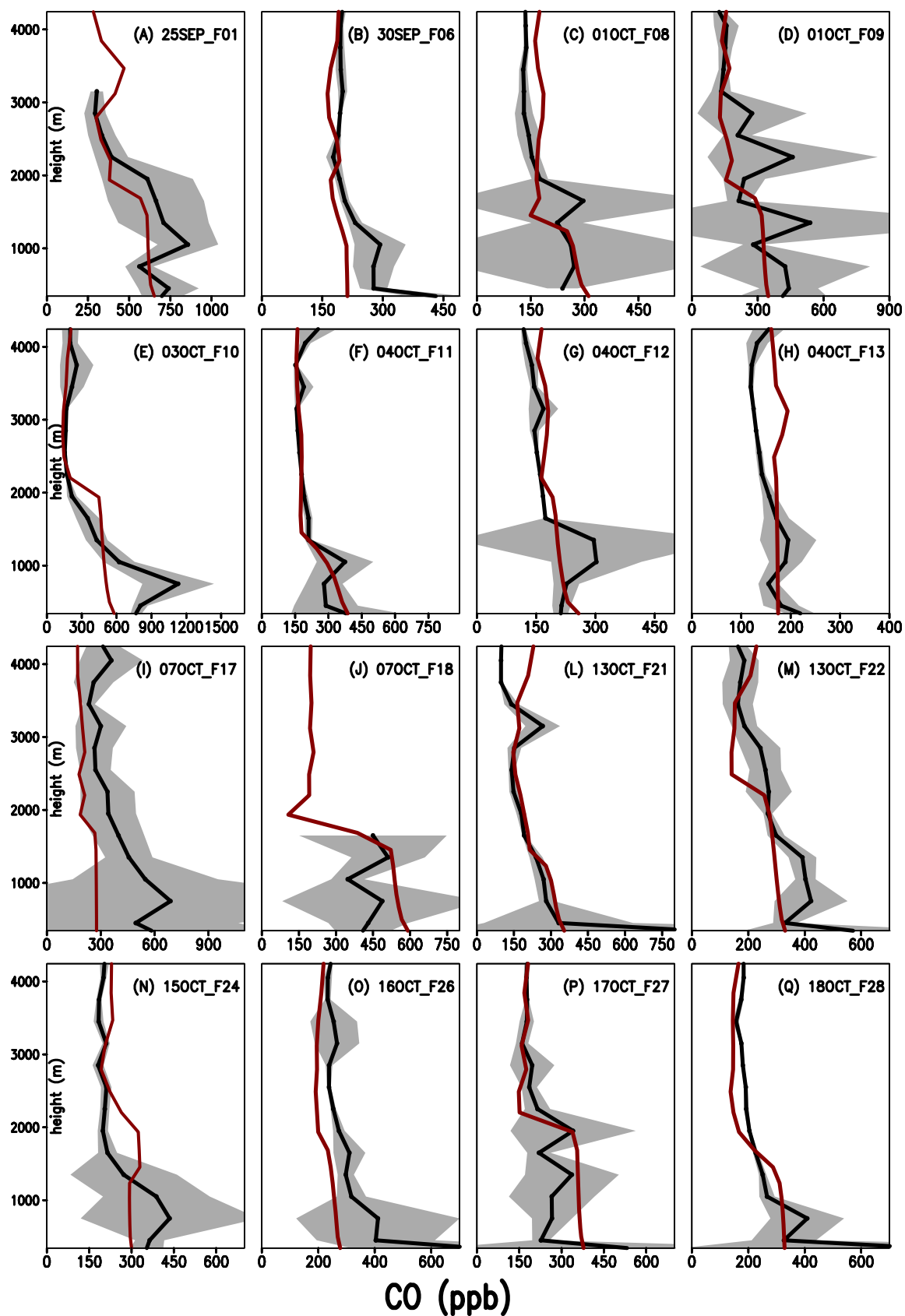

Fig. 14. Comparison between $\mathrm{CO}(\mathrm{ppb})$ observed during sixteen flights of the LBASMOCC/ RaCCI field campaign (black solid line represents the mean while the grey zone shows the standard deviation range) and model results (red).

range of less than $20 \%$, with only few places with larger errors. Southward $30^{\circ} \mathrm{S}$, ME presents higher absolute values mainly in the lower levels. However, in this region it is very difficult to assess the model performance because, since it is not usually affected by the biomass burning emissions in $\mathrm{SA}$, the concentration of tracers is mostly determined by the lateral boundary condition at the model eastern border. Additionally, MOPITT retrievals are less reliable in low levels due to the typically stronger influence of the assumed a priori for retrieved surface level $\mathrm{CO}$ concentration than for higher levels (Deeter et al., 2003). The very noticeable north-tosouth variations in ME, especially at 850 and $700 \mathrm{hPa}$ are due to a well known aspect of the MOPITT method. The MOPITT algorithm was designed to have very simple a-priori assumptions. Aircraft observations suggest that lower tropospheric CO is relatively high with respect to the tropospheric 
$\mathrm{CO}$ profile in the Northern Hemisphere, and relatively low in the Southern Hemisphere. MOPPITT has relatively more information and does not require a-priori assumptions over certain types of land areas. These observations help explain the north-south trend in the $\mathrm{ME}$ and the fact that the trend is most evident over ocean regions (Deeter et al., 2006). Over Africa, the model has its worst performance, which is mainly due to the relatively poor emission estimates for this continent. For the African continent only the MODIS fire product was considered.

From September to October the number of convective systems increases over SA and this fact is reflected in Fig. 16F, $\mathrm{G}, \mathrm{H}, \mathrm{L}, \mathrm{M}$ and $\mathrm{N}$. There is much more $\mathrm{CO}$ above $500 \mathrm{hPa}$ over SA with a clear outflow to the Atlantic Ocean following the westerly jets. The ME over SA is again within a range of less than $20 \%$, with only few places with $30 \%$ or larger errors. Over the Atlantic Ocean, ME is mostly less than $30 \%$, which demonstrates the validity of the numerical results of the model. As pointed out by Freitas et al. (2007), the transport of biomass burning $\mathrm{CO}$ to the upper troposphere is fairly dictated by deep convection and plume rise mechanism. In that way, the model results demonstrate the reliability of the numerical parameterizations of the former processes included in the model system.

Over SA below $500 \mathrm{hPa}$ (Fig. 16I, J, O and P), the model performs satisfactorily as well, with the reasons for larger errors south of $30^{\circ} \mathrm{S}$ and on low levels already discussed. In summary, where the MOPITT data is most reliable, ME is less than $30 \%$ in absolute value.

\subsection{Examples of the model performance from daily- scale cases studies}

Model performance on larger scales and on a daily basis is evaluated in this section through two select cases.

\subsubsection{An upper troposphere case}

We revisited the 6 to 9 September 2002 cold front convective case already discussed by Freitas et al. (2005b), where the model simulation of the effects of a mid-latitude cold front on smoke and $\mathrm{CO}$ transport and distribution is described. A short discussion is given here for convenience. An important effect of a cold front approaching Central Brazil is the northward transport of the regional smoke plume. Following the cold front approach, the polluted air in central South America is replaced by a clean and cold air mass. The smoke is then pushed into the Amazon basin, changing the pristine air composition. Another effect is associated to the vertical transport and scavenging of chemical tracers due to convection triggered by instability areas caused by the cold front. In order to evaluate the convective transport of $\mathrm{CO}$, mostly associated with deep and moist convective systems, we use again the MOPITT data already introduced. Figure 17 presents the model CO mixing ratio (on the left) and the model error (ME)

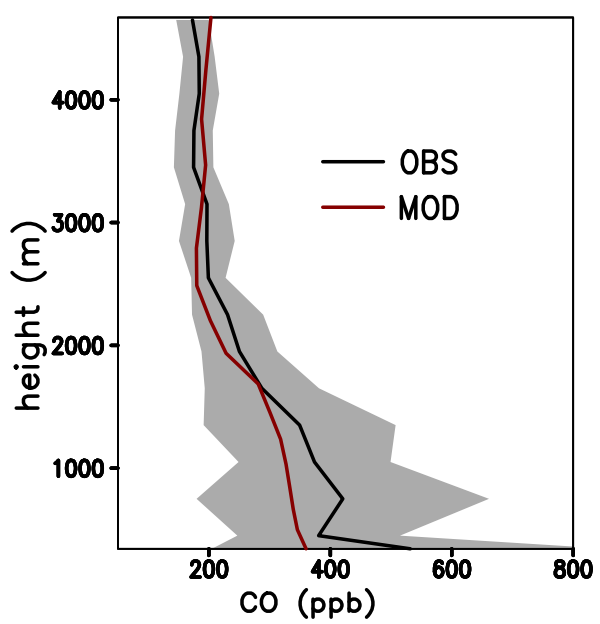

Fig. 15. Comparison between the mean $\mathrm{CO}(\mathrm{ppb})$ observed during sixteen flights of the LBA-SMOCC/RaCCI field campaign (black solid line represents the mean while the grey zone shows the standard deviation range) and the mean of model results (red).

relative to the MOPITT CO retrievals (on the right), at 500, 350 and $250 \mathrm{hPa}$. As before, because the valid MOPITT data are sparse, model and MOPITT data were time averaged over the days 6, 7, 8 and 9 September, approximately the duration of the cold front system event. Figure 17A depicts the upper tropospheric plume of model CO over the central and northeastern part of SA and the South Atlantic Ocean. The resultant enhancement of $\mathrm{CO}$ is around 2-3 times the $60 \mathrm{ppb}$ of background $\mathrm{CO}$. The plume over the ocean is being carried out from the sources area by the westerly jets. The model results can be evaluated through $17 \mathrm{~B}$ with the ME at the same pressure level over both areas, continental and oceanic. The ME is less than $20 \%$, denoting combined good skill of the model and satellite retrievals. The levels 350 (Fig. 17C) and $500 \mathrm{hPa}$ (Fig. 17E) present stronger CO enhancement, with transport mostly to the East (by the westerly jets) and to the West (by the trade winds), respectively. The correspondent model performances are shown in Fig. 17D and F. Again the ME is mostly in between $\pm 20 \%$.

\subsubsection{A lower troposphere case}

Longo et al. (2006b) showed a continental river of smoke bordering on the eastern side of the Andes Mountains on 27 August 2002. This smoke transport was detected by MODIS and was associated with an event of Andes low level jets (Vera et al., 2006). Figure 18A shows the river of smoke in terms of MODIS aerosol column $\left(\mathrm{mg} \mathrm{m}^{-2}\right)$ retrieval (Remer et al., 2006). In spite of the existence of extensive white areas (without valid data), mainly due to cloud contamination, the continental-scale smoke plume traveling from the Amazon basin area to the southern part of SA and exiting towards the South Atlantic Ocean following the circulation 

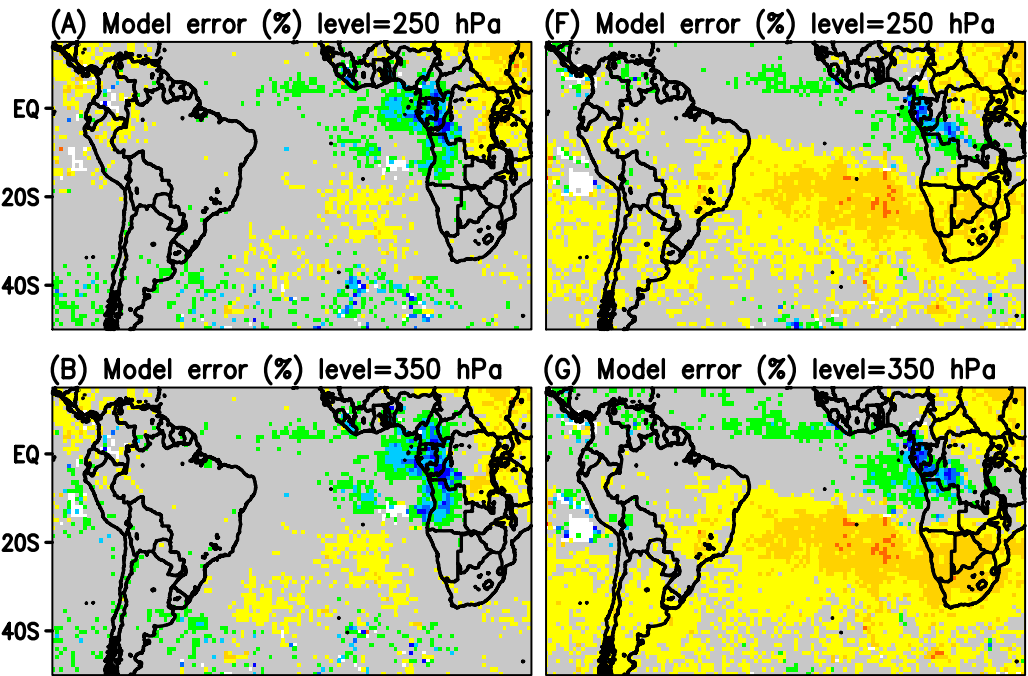

(C) Model error (\%) level $=500 \mathrm{hPa}$

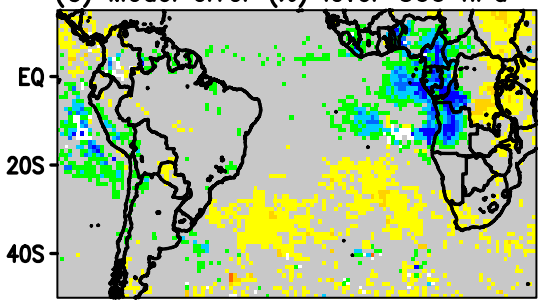

(H) Model error (\%) level $=500 \mathrm{hPa}$

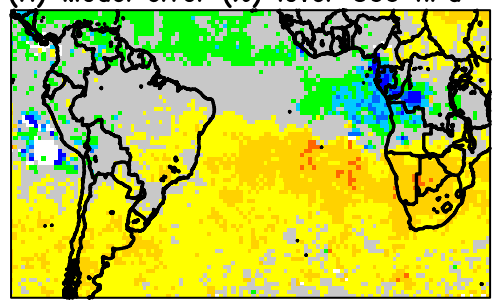

(D) Model error (\%) level $=700 \mathrm{hPa}$

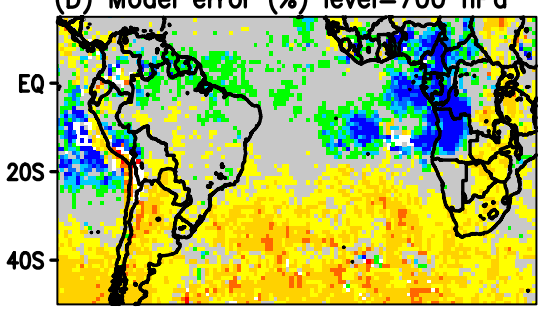

(I) Model error (\%) level $=700 \mathrm{hPa}$

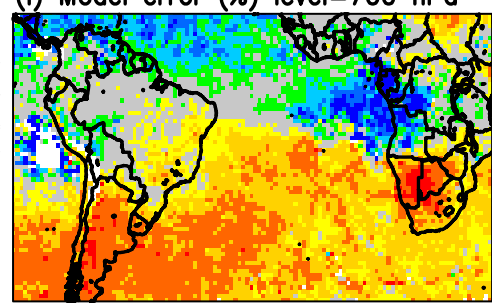

(E) Model error (\%) level $=850 \mathrm{hPa}$

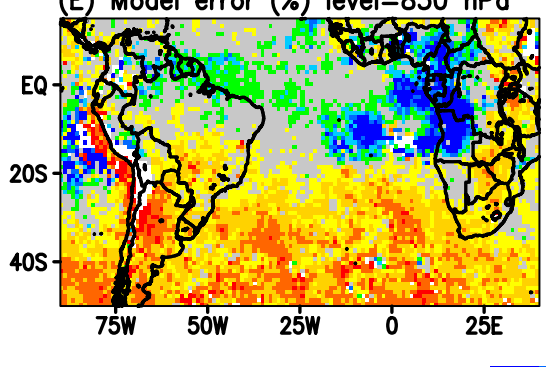

(J) Model error (\%) level $=850 \mathrm{hPa}$

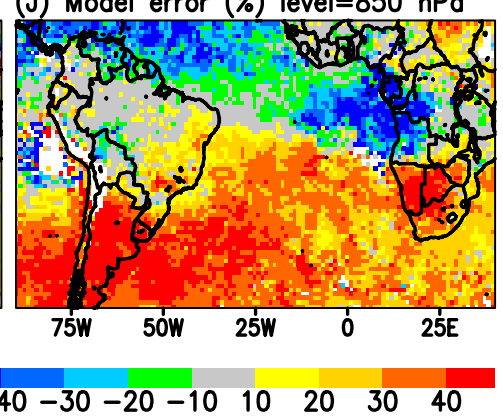

SEPTEMBER

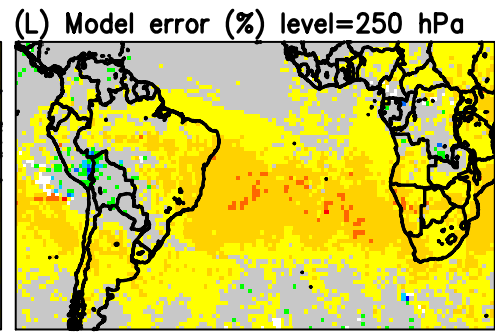

(M) Model error (\%) level $=350 \mathrm{hPa}$

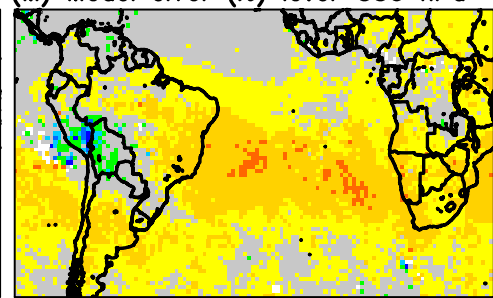

(N) Model error (\%) level $=500 \mathrm{hPa}$

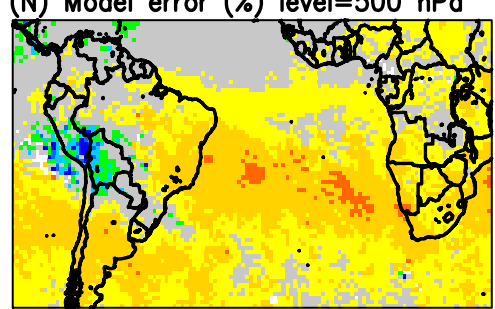

(0) Model error (\%) level $=700 \mathrm{hPa}$

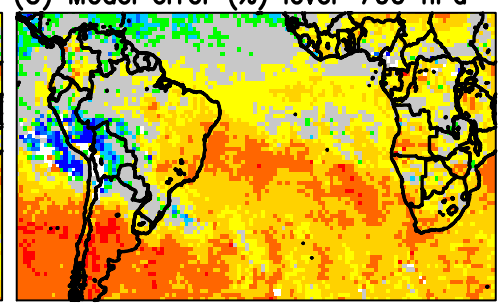

(P) Model error (\%) level $=850 \mathrm{hPa}$

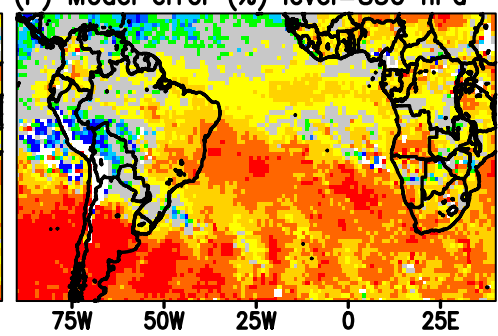

OCTOBER

Fig. 16. CO model relative error $(\%)$ relative to the MOPITT CO retrieval for the months August, September and October 2002 at five vertical levels $(850,700,500,350$ and $250 \mathrm{hPa})$. Positive values mean that model results are underestimated in reference to the MOPITT retrieved data and vice-versa. 

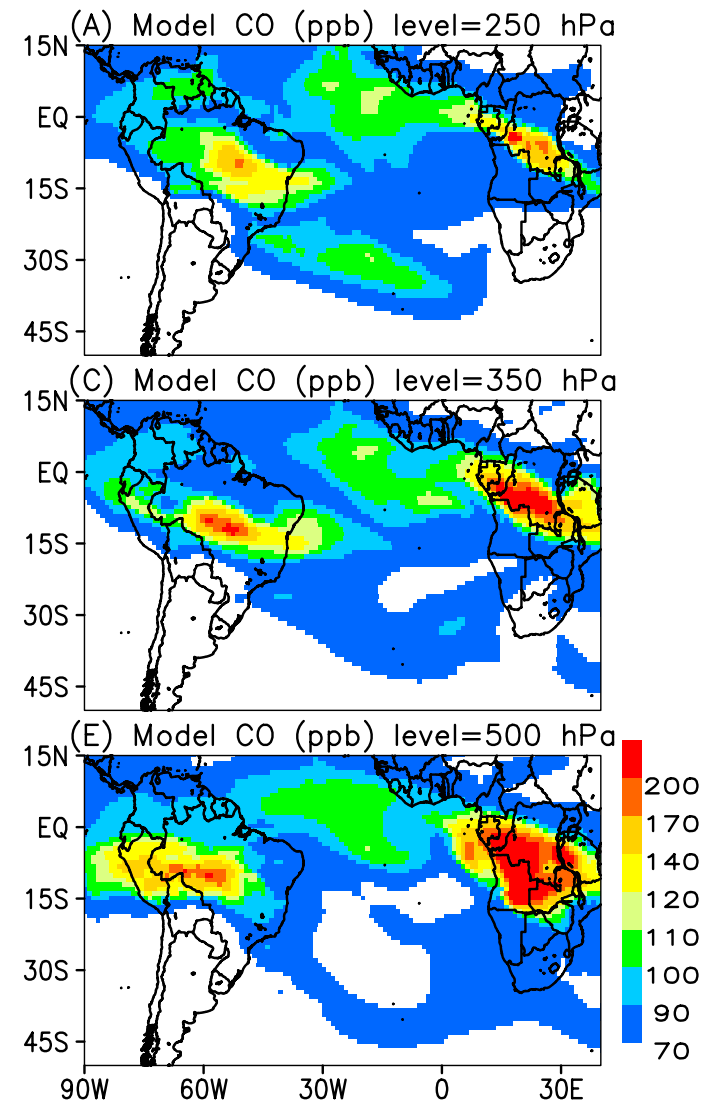

(B) Model error (\%) level $=250 \mathrm{hPa}$

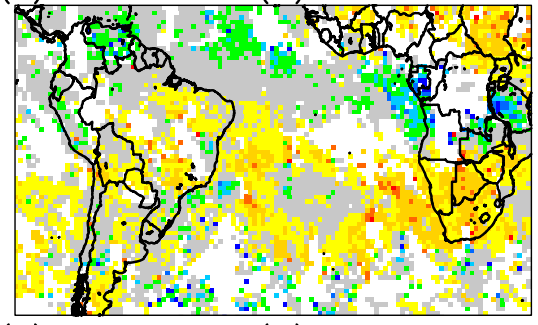

(D) Model error (\%) level $=350 \mathrm{hPa}$

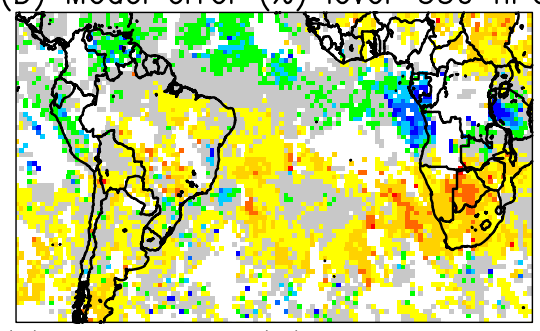

(F) Model error (\%) level $=500 \mathrm{hPa}$

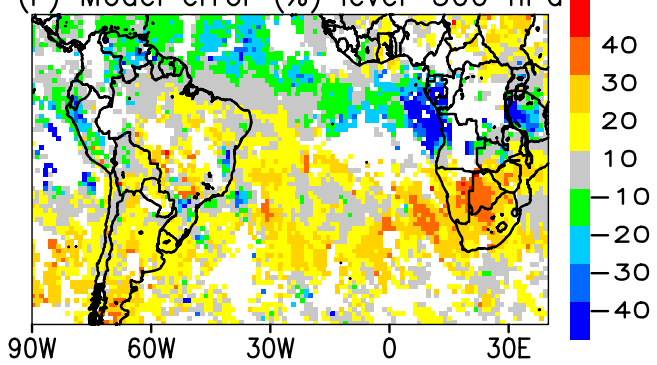

Fig. 17. Model CO mixing ratio (ppb, on the left) and the model error relative to the MOPITT CO retrievals (\%, on the right) at 250,350 and $500 \mathrm{hPa}$. Model and MOPITT data were time averaged over the days 6, 7, 8 and 9 September 2002. White areas, on the right, denote places without valid data for MOPITT during the time average period.

ahead of an approaching cold front (not shown) can be envisioned. Model results as a composite of the regional and large scale grids are shown in Fig. 18B. The pattern of the continental-scale smoke plume are clear in this image and depicts the smoke inflow areas from Africa, the outflow to the South Atlantic Ocean, as well as the emission sources from biomass burning regions. Also the modeled smoke pattern resembles very well the MODIS-retrieved pattern and indicates that the model dynamic works properly. Also this comparison highlights the usefulness of a highly time- and space-resolved, fire-location based emission model (Longo et al., 2007a) because the modeled smoke is then spatially and temporally injected into the atmosphere only where and when fires actually took place. We do not show a statistical analysis between the MODIS aerosol product and model simulation for this case; however, a quantitative visual comparison between the two results can be done from Fig. 18 and shows a high degree of model skill.
(A) MODIS aer. column $\left(\mathrm{mg} / \mathrm{m}^{\wedge} 2\right)$

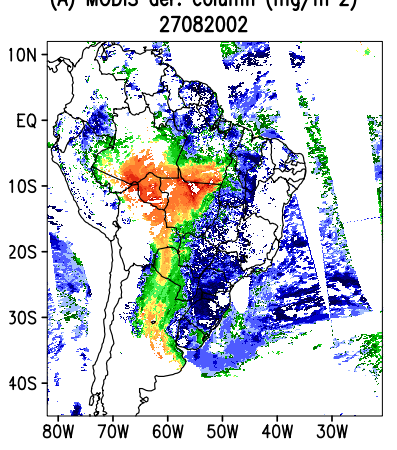

(B) Model aer. column $\left(\mathrm{mg} / \mathrm{m}^{\wedge} 2\right)$

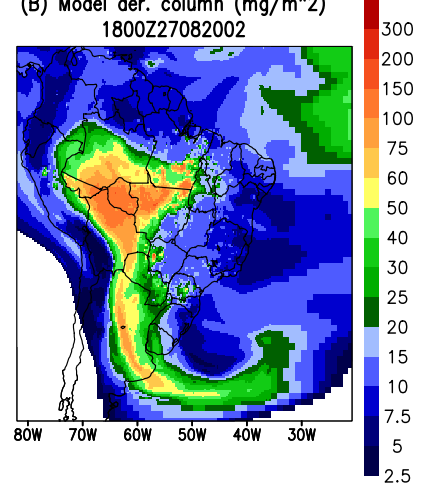

Fig. 18. (A) MODIS aerosol column retrieval $\left(\mathrm{mg} \mathrm{m}^{-2}\right)$ for 27 September 2002; white color denotes areas without valid data (cloud contamination, no sampling, etc.). (B) Model biomass burning $\mathrm{PM}_{2.5}$ column $\left(\mathrm{mg} \mathrm{m}^{-2}\right)$ on 18:00 UTC 27 September 2002. 


\section{Discussion and conclusions}

A description and evaluation of the CATT-BRAMS model is provided in this paper. CATT-BRAMS was primarily designed to study the surface fluxes and atmospheric transport of biomass burning emissions in South America. The atmospheric component of this modeling system (BRAMS) has some implemented features that allow to realistically simulate surface-atmosphere exchanges, planetary boundary layer and cumulus convection on tropical and sub-tropical areas of South America. All these capabilities are essential to any "on-line" tracer transport model be able of consistently simulate the space-time distribution and deposition of tracers, for any kind of sources involved. On the other hand, the tracer simulation component (CATT) has been demonstrated to provide realistic numerical representation of biomass burning transport. The grid-scale advection was able of simulate the continental scale smoke plume. Emission and sub-grid transport mechanisms (PBL diffusion, convective transports and plume rise) were able to properly simulate the tracer mixing ratio from near surface to the upper troposphere, as demonstrated in Sect. 5. Due to these capabilities, this model system has proven to be very useful for the understanding and prediction of the typical controls of synoptic systems on the transport and dispersion of pollutants from biomass burning. Following the validation for the atmospheric transport of passive tracers, a chemical mechanism is being coupled to this system model, to provide a more complete system that will be able to prognosis also reactive chemical species, such as tropospheric ozone produced from precursors emitted by vegetation fires in SA.

It is important to emphasize that the successful compromise between model detail and computational cost achieved in CATT-BRAMS has made possible the operational application of this system for daily numerical air quality monitoring and forecasting over SA, associated with smoke emission from vegetation fires, since 2001. Operational products are available on a daily basis at meio.ambiente.cptec.inpe.br, and have been widely used for several purposes that go from scientific to public health applications (e.g., Andreae et al., 2004; Cordova et al., 2004; Marécal et al., 2006, 2007; Fernandes et al., 2006; Gevaerd et al., 2006B; Ramos et al., 2006; Brazil Health 2006: an analysis of the health situation in Brazil, 2006).

Acknowledgements. We acknowledge partial support of this work by NASA Headquarters (NRA-03-OES-02, NRA-97-MTPE-02 and NRA-02-OES-06), CNPq (305059/2005-0, 309922/2007-0) and FAPESP (04/13445-1, 01/14981-6). This work was carried out within the framework of the LBA Smoke, Aerosols, Clouds, Rainfall, and Climate (SMOCC) project (funded by the Environmental and Climate Program of the European Commission under contract No. EVK2-CT-2001-00110-SMOCC and by the Max Planck Society), and Radiation, Cloud, and Climate Interactions in the Amazon during the DRY-TO-WET Transition Season (RaCCI) project (funded by FAPESP and Instituto do
Milênio/LBA/CNPq/MCT). Partial funding was also provided by Moore Foundation and Inter-American Institute for Global Change Research (IAI) CRN II 2017 and US National Science Foundation (Grant GEO-0452325). The authors also acknowledge L. Emmons for the very constructive comments on a first draft.

Edited by: M. G. Lawrence

\section{References}

Andreae, M. O.: Biomass burning: Its history, use and distribution and its impact on environmental quality and global climate, in: Global Biomass Burning: Atmospheric, Climatic and Biospheric Implications, edited by: Levine, J. S. 3-21, MIT Press, Cambridge, Mass., 1991.

Andreae, M., Rosenfeld, D., Artaxo, P., Costa, A., Frank, G., Longo, K. M., and Silva Dias, M. A. F.: Smoking rain clouds over the Amazon, Science, 303, 1342-1345, 2004.

Araujo, E., Cirne, W. Wagner, G., Oliveira, N., Souza, E. P., Galvão, E. O., and Martins, E. S.: The SegHidro Experience: Using the Grid to Empower a Hydro-Meteorological Scientific Network, Proceedings of the First International Conference on e-Science and Grid Computing (e-Science'05), IEEE Computer Society, 64-71, 2005.

Artaxo, P., Martins, J., Yamasoe, M., Procópio, A., Pauliquevis, T., Andreae, M., Guyon, P., Gatti, L., and Cordova, A.: Physical and chemical properties of aerosols in the wet and dry season in Rondônia, Amazonia, J. Geophys. Res., 107(D20), 49.1-49.14, 2002.

Berge, E.: Coupling of wet scavenging of sulphur to clouds in a numerical weather prediction model, Tellus, 45B, 1-22, 1993.

Brazil Health: an analysis of the health situation in Brazil, Secretaria de Vigilância em Saúde, Departamento de Análise de Situação em Saúde. - Brasília : Ministério da Saúde, Brasil, 620 p. : il. - (Série G. Estatística e Informação em Saúde) ISBN 85-334-1223-1, http://portal.saude.gov.br/portal/arquivos/ pdf/saude_brasil_2006.pdf, 2006.

Brasseur, G., Hauglustaine, D., Walters, S., Rasch, P., Müller, J.-F., Granier, C., and Tie, X.: MOZART, a global chemical transport model for ozone and related chemical tracers, 1: Model description, J. Geophys. Res., 103(D21), 28265-28290, 1998.

Chatfield, R., Guo, Z., Sachse, G., Blake, D., and Blake, N.: The subtropical global plume in the Pacific Exploratory MissionTropics A (PEM-Tropics A), PEM-Tropics B, and the Global Atmospheric Sampling Program (GASP): How tropical emissions affect the remote Pacific, J. Geophys. Res., 107(D16), doi:10.1029/2001JD000497, 2002.

Chatfield, R., Vastano, J., Singh, H., and Sachse, G.: A general model of how fire emissions and chemistry produce African/oceanic plumes (O3, CO, PAN, smoke), J. Geophys. Res., 101, D19, 24279-24306, 1996.

Chin, M., Rood, R., Lin, S.-J., Muller, J.-F., and Thompson, A.: Atmospheric sulfur cycle simulated in the global model GOCART: Model description and global properties, J. Geophys. Res., 105(D20), 24671-24688, doi:10.1029/2000JD900384, 2000.

Cordova, A. M., Longo, K., Freitas, S., Gatti, L. V., Artaxo, P., Procópio, A., Silva Dias, M. A. F., and Freitas, E. D.: Nitrogen oxides measurements in an Amazon site and enhancements associated with a cold front, Atmos. Chem. Phys. Discuss., 4, 
2301-2331, 2004,

http://www.atmos-chem-phys-discuss.net/4/2301/2004/.

Deeter, M. N., Emmons, L. K., Francis, G. L., et al.: Operational carbon monoxide retrieval algorithm and selected results for the MOPITT instrument, J. Geophys. Res., 108(D14), 4399, doi:10.1029/2002JD003186, 2003.

Deeter, M. N., Edwards, D. P, and Gille, J. C.: Retrievals of Carbon Monoxide Profiles from MOPITT Observations using LogNormal A Priori Statistics, submitted, J. Geophys. Res., 2006.

Fast, J. D., Gustafson Jr., W. I., Easter, R. C., et al.: Evolution of ozone, particulates, and aerosol direct radiative forcing in the vicinity of Houston using a fully coupled meteorologychemistry-aerosol model, J. Geophys. Res., 111, D21305, doi:10.1029/2005JD006721, 2006.

Fernandes, W. A., Pinto, I. R. C. A., Pinto Jr., O., Longo, K. M., and Freitas, S. R.: New findings about the influence of smoke from fires on the cloud-to-ground lightning characteristics in the Amazon region, Geophys. Res. Lett., 33, L20810, doi:10.1029/2006GL027744, 2006.

Freitas, E. D., Martins, L. D., and Silva Dias, P. L.: A simple photochemical module implemented in RAMS for tropospheric ozone concentration forecast in the metropolitan area of São Paulo Brazil, Atmos. Environ., 39, 34, 6352-6361, 2005a.

Freitas, S. R.: Modelagem Numérica do Transporte e da Emissão de Gases Traços e Aerossóis de Queimadas no Cerrado e Floresta Tropical da América do Sul, PhD Dissertation, University of São Paulo, 1999.

Freitas, S. R., Silva Dias, M., Silva Dias, P., Longo, K. M., Artaxo, P., Andreae, M. O., and Fischer, H.: A convective kinematic trajectory technique for low-resolution atmospheric models, J. Geophys. Res., 105, D19, 24375-24386, 2000.

Freitas, S. R., Longo, K. M., Silva Dias, M., Silva Dias, P., Chatfield, R., Prins, E., Artaxo, P., Grell, G., and Recuero, F.: Monitoring the transport of biomass burning emissions in South America, Environmental Fluid Mechanics, doi:10.1007/s10652-0050243-7, 5(1-2), 135-167, 2005b.

Freitas, S. R., Longo, K. M., and Andreae, M. O.: Impact of including the plume rise of vegetation fires in numerical simulations of associated atmospheric pollutants, Geophys. Res. Lett., 33, L17808, doi:10.1029/2006GL026608, 2006.

Freitas, S. R., Longo, K. M., Chatfield, R., Latham, D., Silva Dias, M. A. F., Andreae, M. O., Prins, E., Santos, J. C., Gielow R., and Carvalho Jr., J. A.: Including the sub-grid scale plume rise of vegetation fires in low resolution atmospheric transport models, Atmos. Chem. Phys., 7, 3385-3398, 2007, http://www.atmos-chem-phys.net/7/3385/2007/.

Fuzzi, S., Decesari, S., Facchini, M. C., et al.: Overview of the inorganic and organic composition of size-segregated aerosol in Rondônia, Brazil, from the biomass burning period to the onset of the wet season, J. Geophys. Res., 112, D01201, doi:10.1029/2005JD006741, 2007.

Gevaerd, R. and Freitas, S. R.: Estimativa operacional da umidade do solo para iniciação de modelos de previsão numérica da atmosfera. Parte I: Descrição da metodologia e validação, Revista Brasileira de Meteorologia, 21, 3, 1-15, 2006.

Gevaerd, R., Freitas, S. R., Longo, M., Moreira, D. S., Silva Dias, M. A., and Silva Dias, P.: Estimativa operacional da umidade do solo para iniciação de modelos de previsão numérica da atmosfera. Parte II: Impacto da umidade do solo e da parametrização de cumulus na simulação de uma linha seca. Revista Brasileira de Meteorologia, 21, 3a, 74-88, 2006 a.

Gevaerd, R., Freitas, S. R., and Longo, K. M.: Numerical simulation of biomass burning emission and transportation during 1998 Roraima fires. In: International Conference on Southern Hemisphere Meteorology and Oceanography (ICSHMO), 8., 2006, Foz do Iguaçu. Proceedings São José dos Campos: INPE, 883889. CD-ROM. ISBN 85-17-00023-4, 2006b.

Giglio, L., Descloitres, J., Justice, C. O., and Kaufman, Y. J.: An enhanced contextual fire detection algorithm for MODIS, Remote Sens. Environ., 87, 273-282, 2003.

Grell, G. and Devenyi, D.: A generalized approach to parameterizing convection combining ensemble and data assimilation techniques, Geophys. Res. Lett., 29(14), doi:10.1029/2002GL015311, 2002.

Grell, G., Emeis, S., Stockwell, W., Schoenemeyer, T., Forkel, R., Michalakes, J., Knoche, R., and Seidl, W.: Application of a multiscale, coupled MM5/chemistry model to the complex terrain of the VOTALP valley campaign, Atmos. Environ., 34(9), 14351453, 2000.

Grell, G., Peckham, S., Schmitz, R., et al.: Fully coupled "online" chemistry within the WRF model, Atmos. Environ., 39(37), 6957-6975, 2005.

Guyon, P., Frank, G. P., Welling, M., Chand, D., Artaxo, P., Rizzo, L., Nishioka, G., Kolle, O., Fritsch, H., Silva Dias, M. A. F., Gatti, L. V., Cordova, A. M., and Andreae, M. O.: Airborne measurements of trace gases and aerosol particle emissions from biomass burning in Amazonia, Atmos. Chem. Phys., 5, 29893002, 2005, http://www.atmos-chem-phys.net/5/2989/2005/.

Hodnett, M. G., Tomasella, J., and Marques Filho, A.: Comparisons of Long-term Soil Water Storage Behaviour under Pasture and Forest in Three Areas of Amazonia, in: Amazonian Deforestation and Climate, edited by: Gash, J. H. C., Nobre, C. A., Roberts, J. M., Victoria, R. L., John Wiley \& Sons, Chichester, Reino Unido, 57-77, 1996.

Horowitz, L., Walters, S., Mauzerall, D., Emmons, L., Rasch, P., Granier, C., Tie, X., Lamarque, J.-F., Schultz, M., and Brasseur, G.: A global simulation of tropospheric ozone and related tracers: Description and evaluation of MOZART, version 2, J. Geophys. Res., 108(D24), 4784, doi:10.1029/2002JD002853, 2003.

Huffman, G. J., Adler, R. F., Morrissey, M. M., Curtis, S., Joyce, R., McGavock, B., and Susskind, J.: Global precipitation at onedegree daily resolution from multi-satellite observations, J. Hydrometeorol., 2, 36-50, 2001.

Kaufman, Y. J.: Remote Sensing of Direct and Indirect Aerosol Forcing, in: Aerosol Forcing of Climate, edited by: Charlson, R. J. and Heintzenberg, J., John Wiley \& Sons Ltd., 1995.

Koren, I., Kaufman, Y., Remer, L. A., and Martins, J. V.: Measurement of the Effect of Amazon Smoke on Inhibition of Cloud Formation, Science, 303, 1342-1345, 2004.

Kuo, H. L.: Further studies of the parameterization of the influence of cumulus convection on large-scale flow, J. Atmos. Sci., 31, 1232, 1240, 1974.

Longo, K. M., Freitas, S. R., Setzer, A., Prins, E., Artaxo, P., and Andreae, M. O.: The Coupled Aerosol and Tracer Transport model to the Brazilian developments on the Regional Atmospheric Modeling System (CATT-BRAMS) - Part 2: Model sensitivity to the biomass burning inventories, Atmos. Chem. Phys. Discuss., 7, 8571-8595, 2007, 
http://www.atmos-chem-phys-discuss.net/7/8571/2007/.

Longo, K. M., Freitas, S. R., Silva Dias, M., and Silva Dias, P.: Numerical modelling of the biomass-burning aerosol direct radiative effects on the thermodynamics structure of the atmosphere and convective precipitation. In: International Conference on Southern Hemisphere Meteorology and Oceanography (ICSHMO), 8, Foz do Iguaçu. Proceedings. São José dos Campos, INPE, 121-129. CD-ROM, ISBN 85-17-00023-4, 2006a.

Longo, K. M., Freitas, S. R., Ulke, A. G., and Hierro, R. F.: Transport of biomass burning products in Southeastern South America and its relationship with the South American Low Level Jet East of the Andes. In: International Conference on Southern Hemisphere Meteorology and Oceanography (ICSHMO), 8, Foz do Iguaçu. Proceedings. São José dos Campos, INPE, 121-129, CDROM, ISBN 85-17-00023-4, 2006b.

Marécal, V., Riviére, E. D., Held, G., Cautenet, S., and Freitas, S. R.: Modelling study of the impact of deep convection on the UTLS air composition - Part I: Analysis of ozone precursors, Atmos. Chem. Phys., 6, 1567-1584, 2006,

http://www.atmos-chem-phys.net/6/1567/2006/.

Marécal, V., Durry, G., Longo, K., Freitas, S., Rivière, E. D., and Pirre, M.: Mesoscale modelling of water vapour in the tropical UTLS: two case studies from the HIBISCUS campaign, Atmos. Chem. Phys., 7, 1471-1489, 2007, http://www.atmos-chem-phys.net/7/1471/2007/.

Mellor, G. L. and Yamada, T.: Development of a turbulence closure model for geophysical fluid problems, Rev. Geophys. Space Phys., 20, 851-875, 1982.

Miranda, A. C., Miranda, H. S., Lloyd, J., et al.: Fluxes of carbon, water and energy over Brazilian cerrado: an analysis using eddy covariance and stable isotopes, Plant, Cell and Environment, 20, 315-328, 1997.

Nobre, C. A., Fisch, G., Rocha, H. R., et al.: Observations of the Atmospheric Boundary Layer in Rondônia, in: Amazonian Deforestation and Climate, edited by: Gash, J. H. C., Nobre, C. A., Roberts, J. M., and Victoria, R. L, John Wiley \& Sons, Chichester, Reino Unido, 413-424, 1996.

Prins, E., Feltz, J., Menzel, W., and Ward, D.: An overview of GOES-8 diurnal fire and smoke results for SCAR-B and 1995 fire season in South America, J. Geophys. Res., 103, D24, 3182131835, 1998.

Procópio, A. S., Remer L. A., Artaxo P., Kaufman Y. J., and Holben B. N.: Modeled spectral optical properties for smoke aerosols in Amazonia, Geophys. Res. Lett., 30, 24, 2265-2270, doi:10.1029/2003GL018063, 2003.

Ramos, A. R., Freitas, S. R., Longo, K. M., et al.: Modelagem numérica do transporte de poluentes emitidos por fogos durante a onda de calor no verão de 2003, $6^{\circ}$ Encontro Luso-Espanhol de Meteorologia, $4^{o}$ Simpósio de Meteorologia e Geofísica da APMG (Associação Portuguesa de Meteorologia e Geofísica), 218-224. Sesimbra, 14-17 de Fevereiro de 2005.

Reid, J. S. and Hobbs, P.: Physical and optical properties of young smoke from individual biomass fires in Brazil, J. Geophys. Res., 103, D24, 32013-32030, 1998a.

Reid, J. S. and Hobbs, P.: Physical and optical properties of regional hazes dominated by smoke in Brazil, J. Geophys. Res., 103, D24, 32059-32080, 1998b.

Remer, L. A., Ranré, D., Kaufman, Y., et al.: Algorithm for remote sensing of tropospheric aerosol from MODIS: collection
005: The theoretical basis document. http://modis-atmos.gsfc. nasa.gov/reference_atbd.php, 2006.

Roberts, G. C., Artaxo, P., Zhou, J., Swietlicki, E., and Andreae, M. O. : Sensitivity of CCN spectra on chemical and physical properties of aerosol: A case study from the Amazon Basin, J. Geophys. Res., 107(D20), 8070, doi:10.1029/2001JD000583, 2002.

Rosenfeld, D.: TRMM observed first direct evidence of smoke from forest fires inhibiting rainfall, Geophys. Res. Lett. 26, 20, 3101, 1999.

Rossato, L., Alvalá, R. S., and Tomasella, J.: Climatologia da umidade do solo no Brasil, Anais do XII Congresso Brasileiro de Meteorologia, 1910-1915, 2002.

Satyamurty, P., Nobre, C., and Silva Dias, P.: South America, in: Meteorology of the Southern Hemisphere, edited by: Karoly, D. and Vincent, D.: Meteorological Monographs, 27, 49, 119-139, Am. Meteorol. Soc., Boston, 1998.

Seinfeld, J. and Pandis, S.: Atmospheric Chemistry and Physics, John Wiley \& Sons Inc., New York, 1326 pp., 1998.

Sestini, M., Reimer, E., Valeriano, D., Alvalá, R., Mello, E., Chan, C., and Nobre, C.: Mapa de cobertura da terra da Amazônia legal para uso em modelos meteorológicos, Anais XI Simpósio Brasileiro de Sensoriamento Remoto, 2901-2906, 2003.

Souto, R., Ávila, R., Navaux, P., Py, M. X., Maillard, N., Diverio, T., Velho, H. C., Stephany, S., Preto, A. J., Panetta, J., Rodrigues, E. R., Almeida, E. S., Silva Dias, P. L., and Gandu, A. W.: Processing Mesoscale Climatology in a Grid Environment, Proceedings of the Seventh IEEE International Symposium on Cluster Computing and the Grid - CCGrid, 2007.

Souza, E. P.: Estudo teórico e numérico da relação entre convecção e superficies heterogênias na Região Amazônica, PhD Dissertation, University of São Paulo, 1999.

Tremback, C., Powell, J., Cotton, W., and Pielke, R.: The forward in time upstream advection scheme: Extension to higher orders, Mon. Weather Rev., 115, 540-555, 1987.

Tremback, C. J.: Numerical simulation of a mesoscale convective complex: model development and numerical results, Ph.D. dissertation, Atmos. Sci., No. 465, Colorado State University, Dept. of Atmospheric Science, Fort Collins, CO 80523, 1990.

Tripoli, G. and Cotton, W.: The Colorado State University threedimensional cloud-mesoscale model. Part I: General theoretical framework and sensitivity experiments, J. Res. Atmos., 16, 185219, 1982.

Vera, C., Baez, J., Douglas, M., Emmanuel, C. B., Marengo, J., Meitin, J., Nicolini, M., Nogues-Paegle, J., Paegle, J., Penalba, O., Salio, P., Saulo, C., Silva Dias, M. A., Silva Dias, P., and Zipser, E.: The South American Low-Level Jet Experiment, B. Am. Meteorol. Soc., 87(1), 63-77, 2006.

von Randow, C., Manzi, A. O., Kruijt, B., Oliveira, P. J., Zanchi, F. B., Silva, R. L., Hodnett, M. G., Gash, J. H. C., Elbers, J. A., Waterloo, M. J., Cardoso, F. L., and Kabat, P.: Comparative measurements and seasonal variations in energy and carbon exchange over forest and pasture in South West Amazonia, Theor. Appl. Climatol., 78(1), 5-26, 2004.

Walko, R., Band, L., Baron, J., Kittel, F., Lammers, R., Lee, T., Ojima, D., Pielke, R., Taylor, C., Tague, C., Tremback, C., and Vidale, P.: Coupled atmosphere-biophysics-hydrology models for environmental modeling, J. Appl. Meteorol., 39, 6, 931-944, 2000 . 
Wang, J., Christopher, S. A., Nair, U. S., et al..: Mesoscale modeling of Central American smoke transport to the United States: 1. "Top-down" assessment of emission strength and diurnal variation impacts, J. Geophys. Res., 111, D05S17, doi:10.1029/2005JD006416, 2006.
Wesely, M. L.: Parameterizations of surface resistance to gaseous dry deposition in regional scale numerical models, Atmos. Environ., 23, 1293-1304, 1989. 